\author{
Marquette University \\ e-Publications@Marquette
}

$12-20-2020$

\title{
The Electronic Properties of Ni(PNN) Pincer Complexes Modulate Activity in Catalytic Hydrodehalogenation Reactions
}

Denan Wang

Marquette University, denan.wang@marquette.edu

James R. Gardinier

Marquette University, james.gardinier@marquette.edu

Follow this and additional works at: https://epublications.marquette.edu/chem_fac

Part of the Chemistry Commons

\section{Recommended Citation}

Wang, Denan and Gardinier, James R., "The Electronic Properties of Ni(PNN) Pincer Complexes Modulate Activity in Catalytic Hydrodehalogenation Reactions" (2020). Chemistry Faculty Research and Publications. 1012.

https://epublications.marquette.edu/chem_fac/1012 
Marquette University

e-Publications@Marquette

\section{Chemistry Faculty Research and Publications/College of Arts and Sciences}

This paper is NOT THE PUBLISHED VERSION.

Access the published version via the link in the citation below.

European Journal of Inorganic Chemistry, Vol. 2020, No. 47 (December 20, 2020): 4425-4434. DOI. This article is (C) Wiley and permission has been granted for this version to appear in $\underline{\text { e- }}$ Publications@Marquette. Wiley does not grant permission for this article to be further copied/distributed or hosted elsewhere without the express permission from Wiley.

\section{The Electronic Properties of Ni(PNN) Pincer Complexes Modulate Activity in Catalytic Hydrodehalogenation Reactions}

\section{Denan Wang}

Department of Chemistry, Marquette University, Milwaukee, WI

James R. Gardinier

Department of Chemistry, Marquette University, Milwaukee, WI

\section{Abstract}

Three chloronickel(II) complexes of PNN- pincer ligands with pyrazolyl and diphenylphosphino donors appended to different arms of diarylamido anchors were prepared and fully characterized. The three derivatives (1-OMe, 1-Me, 1- $\mathrm{CF}_{3}$ ) differ only by the identity of the para-aryl substituent on the pyrazolyl arm with 1-OMe being $310 \mathrm{mV}$ easier to oxidize than $1-\mathrm{CF}_{3}$. All three complexes are competent catalysts for hydrodehalogenation reactions of 1-bromooctane and a variety of aryl halides in dimethylacetamide using $\mathrm{NaBH}_{4}$ as both base and hydride source. Comparative studies using diverse substrates showed that catalytic activity correlates with electron donor properties; 1-OMe was superior to the other two. Deuterium labeling studies verified $\mathrm{NaBD}_{4}$ as the deuteride source and excluded solvent-assisted radical pathways. 


\section{Abstract}

[PNN]Ni pincer complexes are efficient catalysts for hydrodehalogenation of 1-bromooctane and aryl halides. The activity of the catalysts increases with the electron donor properties of the redox-active diarylamido ligands.

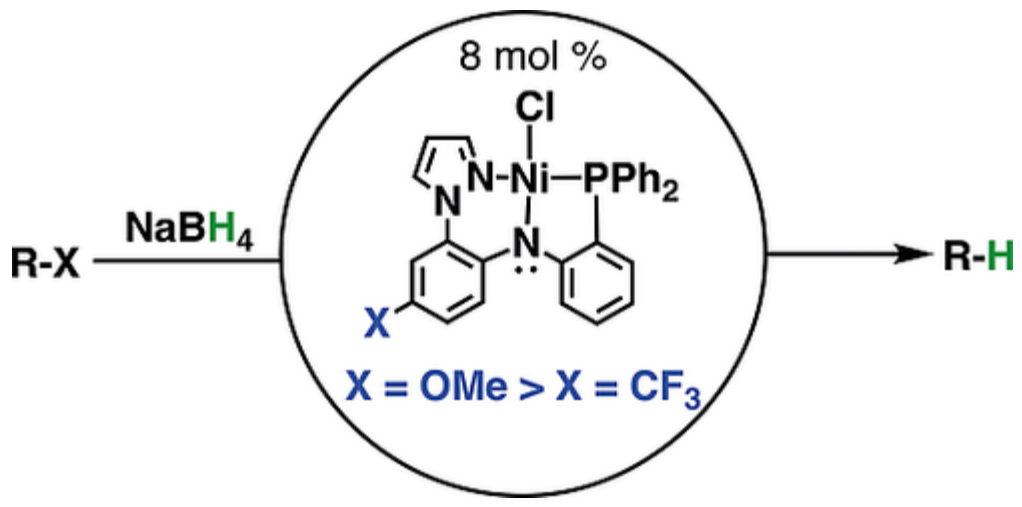

\section{Introduction}

Catalytic hydrodehalogenation $(\mathrm{HDH})$ of organic halides is of great interest in organic synthesis and environmental pollution remediation efforts. ${ }^{[1-5]}$ Among the numerous $\mathrm{HDH}$ methods that have been developed, $\underline{[6-15]}$ nickel pincer complexes have recently emerged as attractive, stable, homogeneous catalysts for such reactions. $\underline{[16-21]}$ In 2012, the Hu group reported that "Nickamine" [16, 22] (complex A in Figure 1 ) could be used as a precatalyst for hydrodehalogenation reactions of both aryl and alkyl halides by employing diethyloxymethylsilane as reductant and sodium methoxide as base.

Rettenmeier, Wadepohl and Gade found that a chiral Ni(NNN) complex, B, (Figure $\underline{1}$ ) can be transformed to a stable $\mathrm{Ni}(\mathrm{I})$ derivative via reaction with $\mathrm{LiBEt}_{3} \mathrm{H}$ and could be used to effect

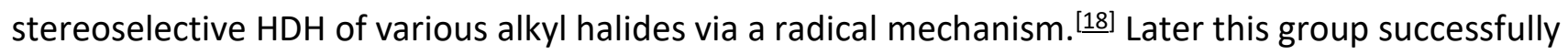
used these catalysts for $\mathrm{HDH}$ of aromatic halides. ${ }^{[19]}$ Norton demonstrated that this pincer complex could even effect Hydrodefluorination reactions. ${ }^{[21]}$ Pincer ligands with other donor atoms were also found to be useful for $\mathrm{HDH}$ reactions. Thus, Enthaler and co-workers ${ }^{[17]}$ used a (ONO)NillPPh ${ }_{3}$ complex, C, (Figure $\underline{1}$ ) in concert with either Grignard or organozinc reagents to effect $\mathrm{HDH}$ of aromatic and alkyl halides. The reaction was thought to proceed via the hydride from $\beta$-hydride elimination of the in-situ generated organonickel species; the expected alkyl-aryl cross-coupling products were the minor by-products of The HDH reaction. It is interesting that ligands with relatively "hard" nitrogen or oxygen donor sets allow for isolation of both low valent nickel species, reactive nickel hydride intermediates while also supporting catalytic activity. 


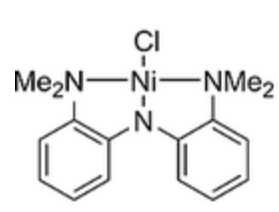

A

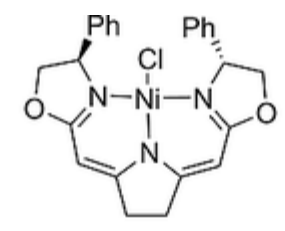

B

(ref. 16)

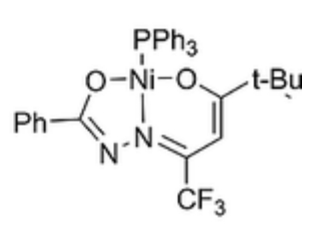

C

(ref. 17)

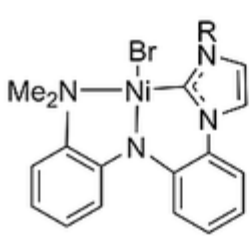

$\mathrm{R}=\mathrm{i}-\mathrm{Pr}, \mathrm{n}-\mathrm{Bu}, \mathrm{Bn}$

$D^{R}$

(ref. 20)

(ref. 18)

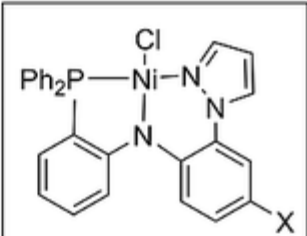

$\mathrm{X}=\mathrm{OMe}, \mathrm{Me}, \mathrm{CF}_{3}$

$1-X$

(This work)

Figure 1 Representative nickel pincer precatalysts used in dehydrohalogenation reactions of organic halides.

A fundamental question prompted by the above results was whether the replacement of one (or both) of the "hard" flanking donors with groups such as carbenes or organophospine donors would still give catalytically active species or whether the hydride or low valent nickel intermediates would be too stable to allow for catalytic turnover. A recent contribution from the Sun group ${ }^{[20]}$ addressed this question. Their carbene-containing pincer complexes ( $N N C) N i B r, D^{R}$ (Figure $\underline{1}$ ), can be converted to (NNC) NiH via reactions with sodium tert-butoxide as a base and triethyloxysilane as a hydride source. These (NNC) NiH can efficiently catalyze HDH reactions of various aryl and alkyl halides where the DiPr variant proved superior to the other two $D^{R}$ complexes.

We sought to extend these studies to pincer complexes with organophosphine donors. Despite numerous (PNN)Ni pincer complexes being known as catalysts for a variety of reactions, $\underline{\text { [23-29] }}$ it was fairly surprising that there were no reports of their use as catalysts for $\mathrm{HDH}$ reactions. Several years ago, our group introduced a PNN pincer type ligand, ( $N$-2-diphenylphosphinophenyl)( $N$-2-pyrazolyl- $p$ tolyl)amine, $\mathrm{H}(\mathrm{PNN}-\mathrm{Me})$, and showed that the hemilabile pyrazolyl arm conferred enhanced reactivity and structural adaptability to stabilize various rhodium(I/III) complexes. $\stackrel{\text { [30] }}{~ T h e ~ m o d u l a r ~ n a t u r e ~ o f ~ t h e ~}$ ligand synthesis suggested a simple means to alter the electron donor strength of the ligand by varying para- aryl substituents. Such variants would be attractive for nickel-catalyzed HDH reactions, in that the stability of any hydride intermediates could be tuned by substitution, thereby influencing the rates of reaction. Herein, we report the preparation and properties of three new nickel(II) pincer complexes, $(\mathrm{PNN}-\mathrm{X}) \mathrm{NiCl}, 1-\mathrm{X}\left(\mathrm{X}=\mathrm{MeO}, \mathrm{Me}\right.$, and $\left.\mathrm{CF}_{3}\right)$ (Figure 1, bottom right) and disclose our initial findings regarding their ability to catalyze $\mathrm{HDH}$ reactions of aromatic and alkyl halides.

\section{Results and Discussion}

An overview of the syntheses of the ligands and nickel complexes is given in Scheme $\underline{1}$ with synthetic details provided in the Supporting Information. The Cul-catalyzed amination reaction between 1,2diiodobenzene and the known 4-X-2-pyrazol-1-ylaniline, $\mathrm{H}\left(\mathrm{pzAn}^{\mathrm{X}}\right)$, $\left(\mathrm{X}=\mathrm{OMe}, \mathrm{Me}\right.$, or $\left.\mathrm{CF}_{3}\right)$ compounds $s^{[\underline{1}]}$ gives a mixture of mainly the desired compound along with variable amounts of 
unreacted $\mathrm{H}\left(\mathrm{pzAn}^{\mathrm{x}}\right)$ and a di-aminated product that require separation by column chromatography. Attempts to improve yields of this step by using drastically different reaction times, alternative solvents, different catalysts, or adding co-catalysts have not yet been proven successful. The ensuing $\mathrm{Pd}^{0}$ - catalyzed coupling reaction with diphenylphosphine afforded high yields of the desired $\mathrm{H}(\mathrm{PNN}-\mathrm{X})$ ligands as air stable colorless solids. The desired nickel complexes 1-X $\left(\mathrm{X}=\mathrm{OMe}, \mathrm{Me}, \mathrm{CF}_{3}\right)$ were obtained by first mixing a $\mathrm{CH}_{2} \mathrm{Cl}_{2}$ solution of the ligand with a methanol solution of $\mathrm{NiCl}_{2} \cdot 6 \mathrm{H}_{2} \mathrm{O}$ to generate a complex in-situ prior to addition of a commercial $\mathrm{MeOH}$ solution of $\mathrm{NEt}_{4}(\mathrm{OH})$ to deprotonate the ligand which is indicated by the appearance of a characteristic deep green color (vide infra) and partial precipitation. Compounds 1-X exhibit limited solubility in $\mathrm{MeOH}$ which allows a facile means of separation from the soluble $\mathrm{NEt}_{4} \mathrm{Cl}$ by-product. The compounds are soluble in $\mathrm{THF} \mathrm{CH}_{3} \mathrm{CN}$, aromatic and halocarbon solvents but are only very slightly soluble pentane, hexane, $\mathrm{Et}_{2} \mathrm{O}$ and lower alcohols.

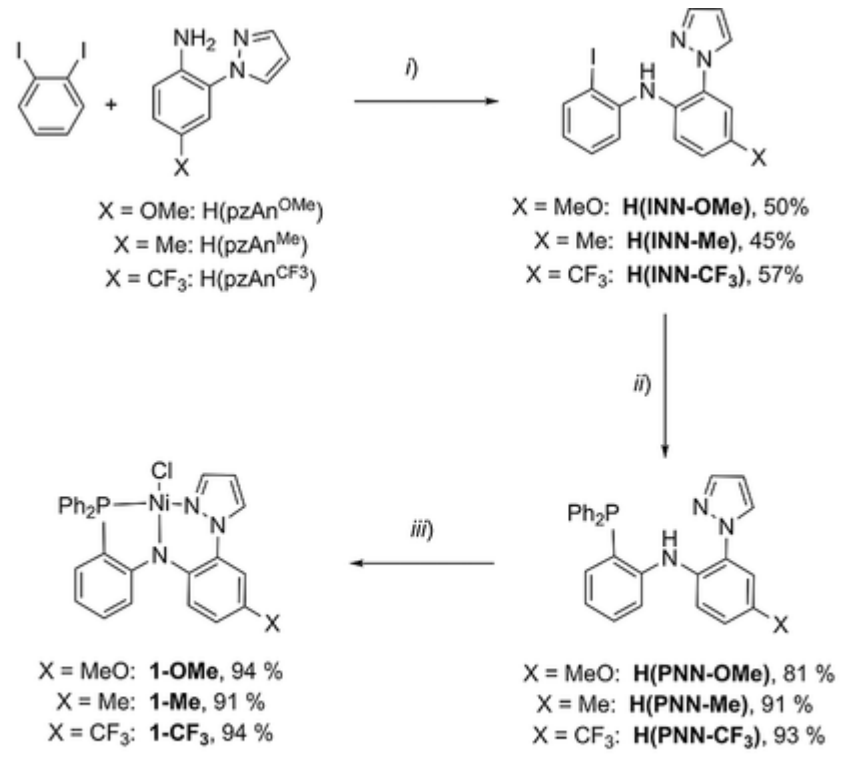

key: i) 1.2 equiv $\mathrm{Cs}_{2} \mathrm{CO}_{3}, 20 \mathrm{~mol} \%$ Cul, dioxane $\Delta, 12 \mathrm{~h}$;

ii) 1.2 equiv. $\mathrm{HPPh}_{2}, 1.2$ equiv $\mathrm{NEt}_{3}, 0.5 \mathrm{~mol} \% \mathrm{Pd}_{2}(\mathrm{dba})_{3}, 1 \mathrm{~mol} \%$ Xantphos, dioxane, $\Delta, 16 \mathrm{~h}$. iii) $\mathrm{NiCl}_{2} \cdot 6 \mathrm{H}_{2} \mathrm{O},\left(\mathrm{NEt}_{4}\right)(\mathrm{OH}), \mathrm{MeOH}: \mathrm{CH}_{2} \mathrm{Cl}_{2}, 3 \mathrm{~h}, 295 \mathrm{~K}$.

Scheme 1 Synthesis of pincer ligands and their chloronickel(II) complexes.

Solid State. Crystals suitable for single-crystal X-ray diffraction were obtained by vapor diffusion of either $\mathrm{Et}_{2} \mathrm{O}(1-\mathrm{Me})$ or pentane (1-OMe and 1- $\mathrm{CF}_{3}$ ) into benzene solutions of the complexes. Views of a representative structure of 1-Me are given in Figure $\underline{2}$, while other structures are provided in Figures S1 and S2. Selected bond lengths and angles are given in Table 1․ Compound 1-Me was found to crystallize as both triclinic needles $(P 1)$ and monoclinic plates $\left(P 2_{1} / n\right)$. The triclinic polymorph has one molecule while the monoclinic form contains two molecules in the asymmetric unit. The former is slightly more dense $\left(1.48 \mathrm{~g} / \mathrm{cm}^{3}\right)$ than the latter $\left(1.42 \mathrm{~g} / \mathrm{cm}^{3}\right)$ which may give rise to the more distorted square planar $\mathrm{NiN}_{2} \mathrm{PCl}$ coordination geometry $\left(\tau_{\delta}=0.16\right.$ dominated by $\left.\mathrm{N} 12-\mathrm{Ni1}-\mathrm{P} 1163.5^{\circ}\right)$ vs. those in the monoclinic form ( $\tau \delta=0.11(\mathrm{Ni1}), 0.05(\mathrm{Ni2})$ ). Despite the angular differences, the bond lengths about nickel in each form are quite similar. The greatest deviation occurs in the Ni1-P1 distance where the more distorted complex has a slightly longer bond $(2.142 \AA)$ than the average $(2.130 \AA)$ found in the monoclinic case. The next biggest difference occurs in the Ni1-Cl1 distance: the triclinic form 
measures $2.181 \AA$, slightly smaller than the average in the monoclinic form $2.185 \AA$. The Ni1-Cl1 distances are at the longer end while the Ni1-P1 distances are at the shorter end of the ranges found in other (PNN)NiCl[26, 28, 29] or (PNP)NiCl[32, 33, 1] complexes. In 1-Me, the five-membered $\mathrm{NC}_{2} \mathrm{PNi}^{2}$ chelate ring adopts an envelope conformation (fold angles $=16.3^{\circ}$ for $P 1,11.0^{\circ}$ and $20.1^{\circ}$ for rings involving Ni1 and $\mathrm{N} 1 \mathrm{a}$, respectively, in the monoclinic form) and the six-membered $\mathrm{NC}_{2} \mathrm{~N}_{2} \mathrm{Ni}$ chelate ring adopts a half-boat conformation to give an overall structure that distinguishes the phenyl rings of the $\mathrm{PPh}_{2}$ group (Figure 2, right), with a pseudoaxial ring (type $\mathrm{A}$ ) being closer to the toluidinyl ring than the pseudoequatorial ring (type $B$ ). In most respects, the structure of 1-OMe is similar to those of 1Me with nearly identical square planar $\left(\tau_{\delta}=0.08\right)$ coordination geometry and bond lengths about the $\mathrm{PN}_{2} \mathrm{NiCl}$ kernel. The envelope fold angle in $1-\mathrm{OMe}$ is more severe $\left(28.0^{\circ}\right)$, which is likely influenced by crystal packing as indicated by the polymorphs of 1-Me. The short C4-O1 bond of the anisidine unit $(1.375(2) \AA)$ in 1-OMe does not impart any significant changes in C-C or C-N bond lengths in the aromatic ring from those displayed by 1-Me. On the other hand, the structure of 1-CF $\mathrm{CF}_{3}$ displays significantly shorter Ni1-Cl1 (2.17 vs. $2.18 \AA$ A ), Ni1-P1 (2.12 vs. $2.13 \AA$ ) and N1-C1 (1.36 vs. $1.40 \AA$ ) bonds than the other two derivatives. Additionally, the Ni1-N1 distance of $1.91 \AA$ is longer than $1.90 \AA$ for 1-OMe, and $1.89 \mathrm{~V}$ (avg.) for 1-Me. These trends may be explained if the inductive effect of the $\mathrm{CF}_{3}$ group weakens the $\mathrm{Ni}-\mathrm{N}_{\text {amido }}$ bond, rendering the metal more electrophilic which is then compensated for by shortening bonds with more polarizable $\mathrm{P}$ and $\mathrm{Cl}$ atoms. The $\mathrm{Ni1}-\mathrm{N} 12\left(\mathrm{Ni}-\mathrm{N}_{\mathrm{pz}}\right)$ distance of $1.94 \AA$ is statistically identical to the other compounds in the series, which is in line the observation that metal-nitrogen (pyrazolyl) bonds are generally more sensitive to oxidation and spin state changes than to inductive effects. $\underline{[34-\underline{37}]}$

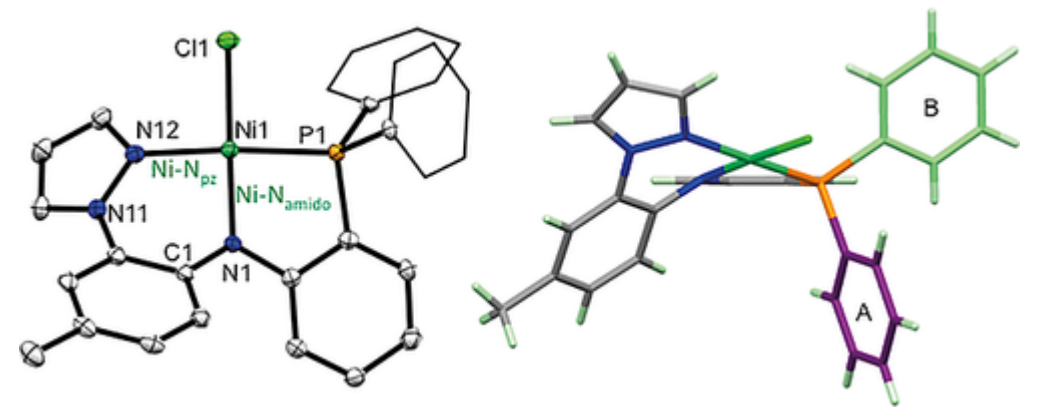

Figure 2 Left: structure of ( $\mathrm{PNN}-\mathrm{Me}) \mathrm{NiCl}(1-\mathrm{Me}, P 1 \mathrm{form})$ with partial atom labelling. Hydrogens and some phenyl carbon ellipsoids were removed for clarity; right: view parallel with the $\mathrm{C}_{6} \mathrm{H}_{4}$ moiety showing the envelope conformation of the $\mathrm{C}_{2} \mathrm{NPNi}$ chelate ring and the distinguishable phosphinophenyl groups ( $A$ and $B$ ).

Table 1. Selected bond lengths $[\AA]$ and angles $\left({ }^{\circ}\right)$ for (PNN-OMe)NiCl (1-OMe), two forms of (PNN-

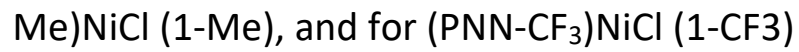

\begin{tabular}{|c|c|c|c|c|}
\hline Distances[Å] & 1-OMe & 1-Me $(P 1)$ & 1-Me $\left(P 2_{1} / n\right)^{[} \underline{a}^{]}$ & $1-\mathrm{CF}_{3}$ \\
\hline $\mathrm{Ni1}-\mathrm{Cl}$ & $2.1825(4)$ & $2.1808(5)$ & 2.1854(8), & $2.1718(10)$ \\
\hline $\mathrm{Ni1a}-\mathrm{Cl} 1 \mathrm{a}$ & & & $2.1855(8)$ & \\
\hline Ni1-P1 & $2.1285(4)$ & $2.1421(5)$ & 2.1271(8), & $2.1226(9)$ \\
\hline Ni1a-P1a & & & $2.1343(8)$ & \\
\hline Ni1-N1 & $1.8992(13)$ & $1.8895(15)$ & 1.894(2), & $1.912(3)$ \\
\hline $\mathrm{Ni1a}-\mathrm{N} 1 \mathrm{a}$ & & & $1.887(2)$ & \\
\hline $\mathrm{Ni1}-\mathrm{N} 12$ & $1.9412(13)$ & $1.9306(16)$ & 1.943(2), & $1.941(3)$ \\
\hline
\end{tabular}




\begin{tabular}{|l|l|l|l|l|}
\hline Ni1a-N12a & & & $1.923(2)$ & \\
\hline Angles $\left(^{\circ}\right)$ & & & & \\
\hline Cl1-Ni1-N1 Cl1a-Ni1a-N1a & $176.64(4)$ & $173.37(5)$ & $175.36(8)$ & $175.97(8)$ \\
\hline & & & $177.43(8)$ & \\
\hline N12-Ni1-P1 & $172.52(4)$ & $163.50(5)$ & $169.38(7)$, & $172.44(8)$ \\
\hline N12a-Ni1a-P1a & & & $176.02(8)$ & \\
\hline Cl1-Ni1-N12 & $93.62(4)$ & $92.04(5)$ & $92.50(7)$, & $93.80(8)$ \\
\hline Cl1a-Ni1a-N12a & & & $91.83(7)$ & \\
\hline Cl1-Ni1-P1 & $93.103(17)$ & $92.74(2)$ & $89.73(3)$, & $91.78(4)$ \\
\hline Cl1a-Ni1a-P1a & & & $91.18(3)$ & \\
\hline N1-Ni1-N12 & $89.58(6)$ & $90.14(7)$ & $91.96(10)$, & $89.86(11)$ \\
\hline N1a-Ni1a-N12a & & & $90.71(10)$ & \\
\hline N1-Ni1-P1 & $83.76(4)$ & $86.89(5)$ & $86.11(7)$, & $84.72(8)$ \\
\hline N1a-Ni1a-P1a & & & $86.30(8)$ & \\
\hline
\end{tabular}

a Two molecules in asymmetric unit.

Solution. The solution structures of the three 1-X compounds elucidated by NMR methods match expectations based on the solid-state structures. First, each ${ }^{31} \mathrm{P}$ NMR spectrum contains a single resonance near $\delta_{p}=30 \mathrm{ppm}$ that is significantly shifted downfield from the resonance for the appropriate free $\mathrm{H}(\mathrm{PNN}-\mathrm{X})$ ligand $\left(\delta_{\mathrm{P}}=-19.5,-18.3\right.$, and $-16.5 \mathrm{ppm}$ for $\mathrm{X}=\mathrm{OMe}, \mathrm{Me}$, and $\mathrm{CF}_{3}$, respectively) due to binding the nickel center. A combination of 2D NMR techniques (COSY, HMQC, $\mathrm{HMBC}$ ) was used to unravel the rather complex ${ }^{1} \mathrm{H}$ and ${ }^{13} \mathrm{C}$ NMR spectra (see Supporting information). The complexity arises both due to detectible ${ }^{1} \mathrm{~J}$ to ${ }^{4} \mathrm{~J}$ coupling of ${ }^{1} \mathrm{H}$ and ${ }^{13} \mathrm{C}$ nuclei with the ${ }^{31} \mathrm{P}$ nucleus and because of the two sets of multiplet resonances for distinguishable phenylphosphino groups (types $A$ and $B$, as in the right of Figure 2 ) that overlap and sometimes mask other resonances. A few points are worthy of mention regarding the NMR analysis. First, in the ${ }^{1} \mathrm{H} N M R$ spectra, the resonances for pyrazolyl hydrogen atom are readily identified at $\delta_{H}=8.1\left(\mathrm{H}_{5}\right), 8.0\left(\mathrm{H}_{3}\right)$ and $6.6\left(\mathrm{H}_{4}\right) \mathrm{ppm}$. The assignment of the latter is straightforward due its characteristic chemical shift, but the former two are tentative (vide infra), being based on both different ${ }^{13} \mathrm{C}$ resonance multiplicities and ${ }^{1} \mathrm{H}-{ }^{13} \mathrm{C}$ HMQC cross peaks with corresponding resonances near $\delta_{C}=128.6\left({ }^{3} J_{c-p}\right.$ doublet, $\left.C_{3}\right)$ and 143.0 (singlet, $\left.C_{5}\right)$ ppm. Of the aromatic resonances, those of the $\mathrm{PPh}_{2}$ group are the least electron rich and appear most downfield. Of these, the resonances for ortho-hydrogens appear as two doublet-of-doublets $\left({ }^{3} J_{H-P}\right.$ ca. $12 \mathrm{~Hz},{ }^{3} \mathrm{~J}_{\mathrm{HH}} \mathrm{ca} .8 \mathrm{~Hz}$ ) near 7.97 and $7.87 \mathrm{ppm}$; the assignment to type $B$ and $A$ rings, respectively, was arbitrary and could be reversed. Their relationship to the corresponding para- and meta-hydrogens (as well as to particular ipso-carbons) was established by both ${ }^{1} \mathrm{H}-{ }^{1} \mathrm{H}$ COSY, $\mathrm{HMQC}$, and $\mathrm{HMBC}$ experiments. The resonances for the three ring hydrogens of the pyrazolyl-aniline group are readily identified by their characteristic multiplicities in the $\delta_{H}=6.7$ to $7.4 \mathrm{ppm}$ region. For 1-OMe and 1-Me, the ${ }^{13} \mathrm{C}$ NMR resonances of this group are distinguished because they are too remote to display ${ }^{13} \mathrm{C}-{ }^{31} \mathrm{P}$ coupling. For $1-\mathrm{CF}_{3}$, the $\mathrm{CF}_{3}$ and $\mathrm{C}_{3^{-}}, \mathrm{C}_{4^{-}}$, and $\mathrm{C}_{5}$ nuclei of the aromatic aniline ring give characteristic quartet resonances due to ${ }^{13} \mathrm{C}-{ }^{19} \mathrm{~F}$ coupling. Finally, the 2-phosphinoaniline group is the most electron rich aromatic ring and the ${ }^{1} \mathrm{H}$ corresponding resonances are generally furthest upfield, below about $\delta_{\mathrm{H}}=7.05 \mathrm{ppm}$, with the $\mathrm{H}_{3}$ - (ortho- to $\mathrm{N}$ ) multiplet resonance near $\delta_{\mathrm{H}}=6.58 \mathrm{ppm}$ being the most distinguishable. Similarly, in the ${ }^{13} \mathrm{C}$ NMR spectrum the associated $\mathrm{C}_{3}$ - doublet resonance is uniquely upfield $\left(\delta_{c}=119 \mathrm{ppm}\right)$ while that for the $\mathrm{C}_{2}$-ring $\left(4^{\circ}\right.$ center, ipso- $\left.\mathrm{N}\right)$ is the most downfield aromatic doublet resonance at ca. $\delta_{C}=163 \mathrm{ppm}$. Interestingly, the $C_{6}$ ring nuclei (ortho- to $\mathrm{P}$ ) that was expected 
to appear as a doublet with ${ }^{2} J_{C-p}$ coupling ca. $25 \mathrm{~Hz}$ (similar to the $\mathrm{C}_{2}$ - resonance) appears as a singlet. Its identity was verified by both $\mathrm{HMQC}$ and the strong three-bond $\mathrm{HMBC}$ cross peak with the $\mathrm{H}_{4}$ resonance. Thus, assignments based on the magnitude of $J_{C-p}$ coupling, such as those for the $\mathrm{H}(\mathrm{C})_{3 / 5}$ nuclei above, are tenuous and could be reversed.

The electronic properties of the three 1-X compounds were studied by electronic absorption spectroscopy, electrochemistry (square-wave and cyclic voltammetry) and by computational methods (DFT and TD-DFT). A summary of calculated and experimental properties is given in Table $\underline{2}$. It is useful to first describe frontier orbitals of the complexes to facilitate discussion of electronic properties. The frontier orbitals of 1-Me and 1- $\mathrm{CF}_{3}$ are nearly identical to 1-OMe (except for relative energies), so only those of the latter will be discussed. The frontier orbitals of 1-OMe calculated at the M06/def2-SV(P) level are provided in Figure $\underline{3}$. Full computational details including more complete diagrams for the series of $1-X$ are provided in the supporting information (Figures S23-S25). As indicated in Figure $\underline{3}$, the HOMO of 1-OMe is mainly a pincer ligand $\pi$-orbital mixed in a $\pi^{*}$ manner with a minor contribution from nickel's $3 d_{y z}$ orbital. The $3 d_{y z}$ orbital is mainly involved in $d \pi-p \pi$ interactions with the chloride $p_{z}$ orbitals where the $\pi^{*}$ combination found in $\mathrm{HOMO}(-2)$ and the corresponding $\pi$-bonding component comprises HOMO (-11 and -13$)$, Figure S23. The HOMO(-1) is mainly nickel's $3 \mathrm{~d}_{z^{2}}$ orbital involved in $\sigma^{*}$-interactions with $\mathrm{P}$ and anilino-N orbitals with minor contributions from the ligand $\pi$ system and chloride $p_{y}$ orbital. The LUMO has the $\mathrm{Ni} 3 d_{x^{2}-y^{2}}$ involved in a classical $\sigma^{*}$ interaction with ligand group orbitals, while the LUMO $(+N)(N=1-7)$ are exclusively ligand based $\pi^{*}$ orbitals.

Table 2. Summary of experimental and calculated (M06/def2-SV(P)/PCM $\left(\mathrm{CH}_{2} \mathrm{Cl}_{2}\right)$ ) properties for 1-X (X $=\mathrm{OMe}, \mathrm{Me}, \mathrm{CF}_{3}$ )

\begin{tabular}{|l|l|l|}
\hline Compound & $\mathrm{E}^{\prime}{ }_{1+1}, \mathrm{~V}^{[} \underline{\underline{a}}^{]}$ & $\mathrm{UV} / \mathrm{Vis}\left(\mathrm{CH}_{2} \mathrm{Cl}_{2}\right) \lambda_{\max }, \mathrm{nm},\left(\varepsilon, \mathrm{M}^{-1} \mathrm{~cm}^{-1}\right)$ \\
\hline 1-OMe exp. & $+0.51 \underline{\underline{b}}^{\underline{b}}$ & $660(930), 480 \mathrm{sh}(1100), 429(3200), 334(8340)$ \\
\hline (Calcd) & +0.52 & $820(175), 604(540), 391,(7940), 339(9710)$ \\
\hline $1-M e$ exp. & $+0.59{ }^{[} \underline{b}^{]}$ & $656(910), 478 \mathrm{sh}(1100), 419(3100), 334(9040)$ \\
\hline (Calcd) & +0.61 & $832(154), 604(480), 391,(7900), 339(11200)$ \\
\hline $1-\mathrm{CF}_{3}$ exp. & $+0.82^{[} \underline{b}^{]}$ & $630(780), 470(830), 395(3100), 355(7700)$ \\
\hline (Calcd) & +0.91 & $841 \mathrm{sh}(140), 606(425), 373(8032), 328(14900)$ \\
\hline
\end{tabular}

a v v. AgAgCl.

${ }^{b}$ In $\mathrm{CH}_{2} \mathrm{Cl}_{2}, \mathrm{NBu}_{4} \mathrm{PF}_{6}$ as supporting electrolyte, average of potentials acquired at scan rates of $100,200,300$, and $400 \mathrm{mV} / \mathrm{s}$. 

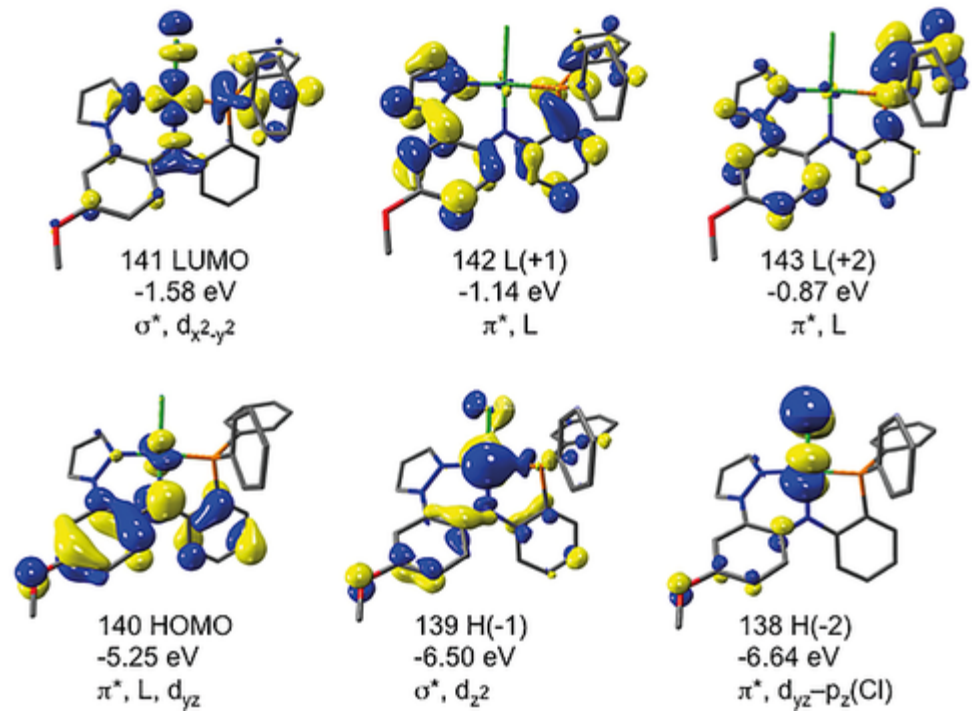

Figure 3 Selected frontier orbitals for 1-OMe calculated at the M06/def2-SV $(\mathrm{P}) / \mathrm{PCM}\left(\mathrm{CH}_{2} \mathrm{Cl}_{2}\right)$ level of theory with orbital number, energies, and main contributions shown.

The three 1-X complexes exhibit reversible oxidations (Figure 4) whose $\left.\mathrm{E}^{\prime}(1-\mathrm{x})\right)^{+/(1-\mathrm{X})}$ reduction potentials scale linearly with the electron donating nature of the para-anilino substituent as quantified using the substituent's Hammett $\sigma_{\text {para }}$ parameter ${ }^{[38]}$ (Figure $\left.\mathrm{S} 18\right)$. That is, 1-OMe is easier to oxidize $\left(E^{\prime}(1-\mathrm{OMe})+/ 1\right.$ $\left.\mathrm{OMe}=0.51 \mathrm{~V} \mathrm{vs} . \mathrm{Ag} / \mathrm{AgCl}, \sigma_{\text {para }}=-0.27\right)$ than $1-\mathrm{CF}_{3}\left(\mathrm{E}^{\prime}(1-\mathrm{CF} 3)^{+} /(1-\mathrm{CF} 3)=0.82 \mathrm{~V} \mathrm{vs} . \mathrm{Ag} / \mathrm{AgCl} \sigma_{\text {para }}=+0.54\right)$. It is also noted that the calculated oxidation potentials give excellent agreement with the experimental values, providing another measure (along with excellent agreement of bond lengths) to validate our choice of using this DFT model. Finally, as can be elucidated by inspection of the HOMO in 1-OMe or of the Mulliken spin-densities of atoms in (1-OMe) $)^{+}$(Figure 4, right), the oxidation event of 1-OMe is mainly $(88 \%)$ ligand-based such that $(1-\mathrm{OMe})^{+}$is best described as $\mathrm{Ni}^{\mathrm{I}}-\mathrm{L}^{+}$, rather than $\left(\mathrm{Ni}^{\mathrm{III}}-\mathrm{L}\right)^{+}$.

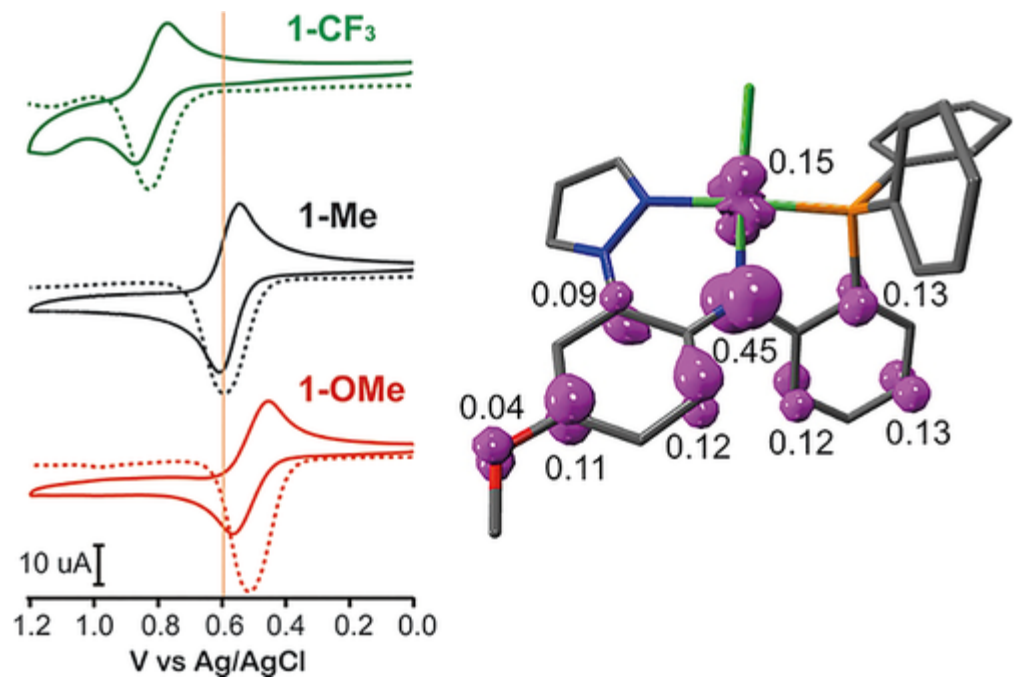

Figure 4 Left: cyclic voltammograms obtained for 1-X ( $\left.\mathrm{X}=\mathrm{OMe}, \mathrm{Me}, \mathrm{CF}_{3}\right)$ at a scan rate of $200 \mathrm{mV} / \mathrm{s}$ in $\mathrm{CH}_{2} \mathrm{Cl}_{2}$ with $\mathrm{NBu}_{4} \mathrm{PF}_{6}$ as a supporting electrolyte; right: Mulliken spin densities and isosurface (isovalue 0.05 ) of (1-OMe) $)^{+}$. 
An overlay of the UV/Visible spectra of the three 1-X compounds is shown in Figure $\underline{\mathbf{5}}$ while data are summarized in Table $\underline{2}$. Details regarding calculated (time-dependent density functional theory, TDDFT) spectra along with calculated spectra are provided in the Supporting information (Figures S26S27). The lowest energy and least intense ( $\varepsilon$ ca. 800 to $1000 \mathrm{M}^{-1} \mathrm{~cm}^{-1}$ ) band in the 600 to $750 \mathrm{~nm}$ range gives rise to the green or green blue color of the complexes. The modest intensity and the hypo- and hypso-chromic shifts on ligand substitution of OMe with more electron withdrawing substituents are suggestive of ligand-to-metal charge transfer (LMCT) character. ${ }^{[34]}$ This assertion is also obtained via analysis of TD-DFT results (Tables S5 - S7), albeit not straightforwardly. The lowest energy experimental band is resolved by TD-DFT into disparate bands: a low-intensity $\left(\varepsilon \mathrm{ca} .100 \mathrm{~m}^{-1} \mathrm{~cm}^{-1}\right)$, low-energy (ca. $12,000 \mathrm{~cm}^{-1}, \lambda_{\max }$ ca. $830 \mathrm{~nm}$ ) component $A$ and a more intense $\left(\varepsilon \mathrm{ca} .400-500 \mathrm{M}^{-1} \mathrm{~cm}^{-}\right.$ $\left.{ }^{1}\right)$, higher energy (ca. 16,500 $\mathrm{cm}^{-1}, \lambda_{\max } \mathrm{ca} .605 \mathrm{~nm}$ ) component $B$. These bands involve admixtures of $\mathrm{HOMO}(+\mathrm{N}) \rightarrow$ LUMO transitions where $N=0-2$ (component $\mathrm{A}$ ) and $N=3,5$ (component $\mathrm{B}$ ). Thus all have $d-d$ character but component $\mathrm{A} \mathrm{HOMO}(+\mathrm{N})$ has significant contributions from pincer ligand $\pi$ system and chloride $p_{\mathrm{z}}$ (and to a lesser extend $p_{\mathrm{x}}$ ) orbitals whereas the $\mathrm{HOMO}(+3$ and +5$)$ of component $\mathrm{B}$ have substantial contributions from chloride $p_{\mathrm{x}}$-orbitals (Figure $\mathrm{S} 23$ ) with little or no contribution from pincer ligand orbitals. As such, the energy of the component $A$ band is more ligand dependent than that of component B. In general, transitions involving the ligand-based HOMO as the origin of a transition will experience ligand-dependent hypsochromic shifts along the series 1OMe to 1- $\mathrm{CF}_{3}$, which is exhibited by the next two higher energy bands in the 400-500 nm range of the experimental spectra. These latter two bands are due to overlapping HOMO $\rightarrow$ LUMO $(+0$ and +1$)$ transitions for the lower energy shoulder ( $\lambda_{\text {exper }}$ ca. $470-480 \mathrm{~nm}, \lambda_{\text {TDDFT }}$ ca. $391 \mathrm{~nm}$ ) and to overlapping HOMO $\rightarrow$ LUMO $(+2,+3$, and +4$)$ transitions for the higher energy band $\left(\lambda_{\text {exper }}\right.$ ca. 395-430 $\mathrm{nm}$, $\lambda_{\text {TDDFT }}$ ca. $333 \pm 6 \mathrm{~nm}$ ). The more intense band $\left(\varepsilon\right.$ ca. $9000 \mathrm{M}^{-1} \mathrm{~cm}^{-1}$ ) or split bands $\left(1-\mathrm{CF}_{3}\right)$ near $\lambda_{\text {exper }} \mathrm{ca}$. $350 \mathrm{~nm}$ have MLCT character, being lowest energy for 1-CF 3 and highest for 1-OMe. Accordingly, TDDFT predicts these bands ( $\lambda_{\text {TDDFT }}$ ca. $280 \pm 4 \mathrm{~nm}$ ) to be due to mainly overlapping transitions between metal-based $\operatorname{HOMO}(-1,-2$, or -5$)$ to $\operatorname{LUMO}(+1)$, a pincer $\pi^{*}$ orbital.

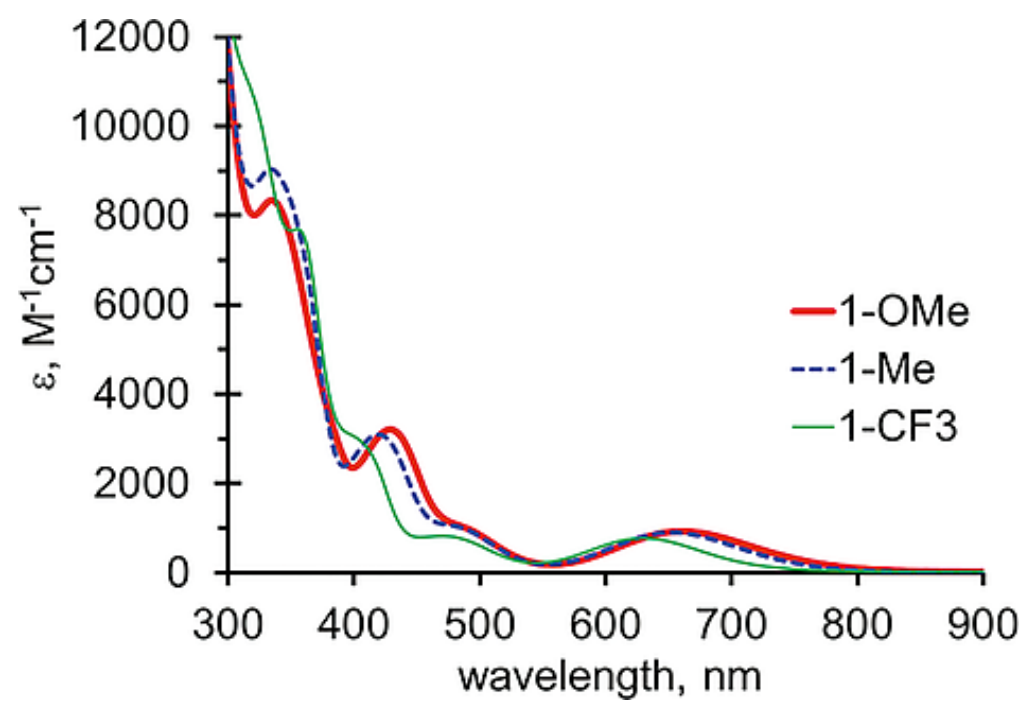

Figure 5 Overlay of the UV/visible spectra of 1-X $\left(X=O M e\right.$, thick solid red line; $X=M e$, dashed blue line; $X=\mathrm{CF}_{3}$, thin solid green line) in $\mathrm{CH}_{2} \mathrm{Cl}_{2}$. 
Catalysis. With the series of electronically diverse nickel pincer complexes in hand, their utility in hydrodehalogenation reactions was investigated. $\mathrm{NaBH}_{4}$ was selected as the hydride source because it is conveniently handled $[\underline{39}, \underline{40]}$ and is, by far, the least expensive of the commonly used reductants. The compound 4- bromobiphenyl was chosen as an initial substrate for reaction optimization because it and its product, biphenyl, are readily available, easily-handled solids that can be reliably quantified both on the spectroscopic and synthetic scale without significant losses due to inadvertent evaporation. A reaction time of $3 \mathrm{~h}$ was arbitrarily chosen for the initial survey as it was reasonably short to allow rapid screening. Fortuitously, this time period provided useful window into reactivity differences, so no further effort was made to optimize the reaction time. A summary of results from $\mathrm{HDH}$ reaction optimization studies is found in Table $\underline{3}$, with the optimized conditions found in entries 1-4. That is, all three complexes were excellent at catalyzing the $\mathrm{HDH}$ reaction of 4-bromobiphenyl at 8 mol-\% loading, with 1-OMe being slightly superior to the other two complexes. The yields of product decrease with lower catalyst loading ( 4 mol-\%, entries $5-7$ ) and the superiority of 1-OMe vs. 1-

Me becomes evident. The 1-X complexes all outperform simple nickel salts and the reaction does not proceed in the absence of nickel (entries 8-12). A control reaction with 1-OMe in the presence of a drop of elemental mercury (entry 2 ), showed no significant reduction in efficiency suggesting that nickel colloids are not responsible for the catalytic activity. A second control (not tabulated) showed that no reaction occurred in the presence of the stable radical 2,2,6,6-tetramethylpiperidinyl-N-oxyl (TEMPO), suggesting either a radical pathway or an irreversible reaction with a non-radical intermediate. In initial temperature screenings, $80^{\circ} \mathrm{C}$ was found to be the optimal reaction temperature to give a maximum yield of biphenyl during the $3 \mathrm{~h}$ reaction time; there was no improvement in reactions performed at $100^{\circ} \mathrm{C}$. Finally, screening different solvents (compare entries 15 and 18-23) showed that DMA was superior to other solvents; the insolubility of $\mathrm{NaBH}_{4}$ being the critical factor in the lack of activity in toluene.

Table 3. Optimization of conditions for hydrodehalogenation of 4-bromobiphenyl using $\mathrm{NaBH}_{4}$ as a reductant $[\underline{a}]$

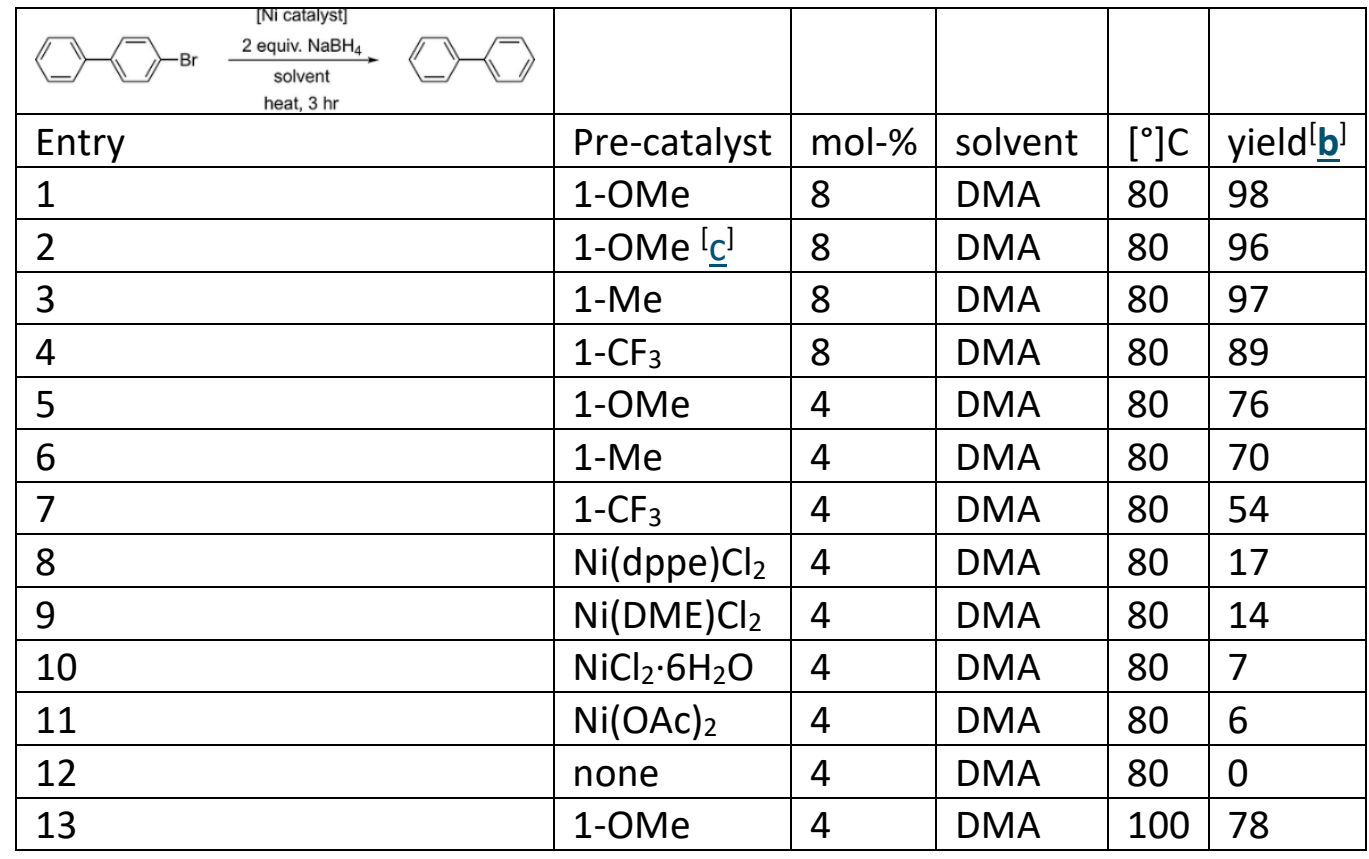




\begin{tabular}{|l|l|l|l|l|l|}
\hline 14 & $1-\mathrm{Me}$ & 4 & DMA & 100 & 67 \\
\hline 15 & $1-\mathrm{Me}$ & 4 & DMA & 60 & 55 \\
\hline 16 & $1-\mathrm{Me}$ & 4 & DMA & 40 & 25 \\
\hline 17 & $1-\mathrm{Me}$ & 4 & DMA & 20 & 7 \\
\hline 18 & $1-\mathrm{Me}$ & 4 & DMF & 60 & 32 \\
\hline 19 & $1-\mathrm{Me}$ & 8 & DMF & 80 & 76 \\
\hline 20 & $1-\mathrm{Me}$ & 4 & THF & 60 & 33 \\
\hline 21 & $1-\mathrm{Me}$ & 4 & dioxane & 60 & 28 \\
\hline 22 & $1-\mathrm{Me}$ & 4 & iPrOH & 60 & 25 \\
\hline 23 & $1-\mathrm{Me}$ & 4 & toluene & 60 & 0 \\
\hline
\end{tabular}

a Typical conditions: $0.2 \mathrm{mmol}$ of 4-bromobiphenyl $(46.6 \mathrm{mg}), 0.016 \mathrm{mmol}$ of Ni catalyst ( $8 \mathrm{~mol}-\%), \mathrm{NaBH}_{4}(15.0$ $\mathrm{mg}, 0.4 \mathrm{mmol}, 2.0$ equiv.) and $2 \mathrm{~mL}$ dimethylacetamide (DMA) or other solvent, heat $3 \mathrm{~h}$.

${ }^{\mathrm{b}} \mathrm{GC} / \mathrm{MS}$ yield, average of three experiments, error $\pm 3 \%$.

${ }^{\mathrm{c}}$ In the presence of $\mathrm{Hg}^{0}(\mathrm{I})$.

Next, the scope of the HDH reactions with a variety of aromatic and alkyl halides was explored, with results provided in Table $\underline{4}$. The conversion of halobenzenes to benzene catalyzed by 1-OMe (under conditions optimized for bromobiphenyl above) decreased up the periodic table being quantitatve for iodobenzene and zero for fluorobenzene (entries 1-4). This trend roughly parallels the expected stability of the corresponding halo radical, but biphenyl was never observed as a by-product. Substrate electronic effects were probed in $\mathrm{HDH}$ reactions of para- $R$-substituted bromobenzenes catalyzed by $1-$ OMe ( $R=$ Ph: Table $\underline{3}$, entry $1 ; R=H$, Me, OMe, CN: Table $\underline{2}$, entries 2, 5, 6, and 9). The yields of the dehalogenated product are suppressed for the electron releasing substituents, $\mathrm{R}=\mathrm{Me}$ and $\mathrm{MeO}$ whereas they are quantitatve for electron withdrawing $\mathrm{CN}$. If one considers Hammett $\sigma_{\text {para }}$ to be indicative of electron releasing capabilities of the $\mathrm{R}$ group, the yield for the conversion of bromobenzene $(R=H)$ is lower than expected; a phenyl is more electron releasing than $H\left(\sigma_{\text {para }}(P h)=-\right.$ 0.01 vs. $\left.\sigma_{\text {para }}(H)=0.00\right)$ yet the yield for $R=P h$ was higher than the $R=H$ case $(98 \%$ vs. $85 \%$ yield, respectively). Other factors such as resonance stabilization of radical species or simply redox potentials may also be (minor) contributing factors in determining conversion. Next, the electronic effects of the $1-X$ catalysts were evaluated for 4-bromoanisole (Table $\underline{4}$, entries $6-8$ ) and 4-bromobenzonitrile (Table $\underline{4}$, entries 10-12) to validate the generality of results observed for 4-bromobiphenyl (Table $\underline{3}$, entries 1 and 3-7) on electronically diverse substrates. All three catalysts were excellent at catalyzing the $\mathrm{HDH}$ reaction of the electron-poor bromobenzonitrile, with 1- $\mathrm{CF}_{3}$ being marginally less efficient than the other two (93\% vs. quantitative conversion). With the more electron rich anisole substrate, the yield increased inversely with (pre)catalyst oxidation potential: 1-CF $(29 \%)<1-\mathrm{Me}(45 \%)<1-$ OMe (55\%). Interestingly, 1-OMe performed as well as "nickamine", A, (Table 4 , entries 8 and 9). Such results suggest that further modifying $1-X$, nickamine or other nickel pincer complexes with electron donor groups might be key to improving catalytic performance toward electron rich aromatics. Next dihalogenated arenes were examined. With 1-OMe as a catalyst, the substrates 1-bromo-2fluorobenzene and 1-bromo-2-fluoro-4-trifluoromethylbenzene (Table $\underline{4}$, entries 12 and 13) underwent exclusive debromination with the more electron-deficient tri-substituted derivative reacting faster, giving quantitative conversion with half the catalytic loading and only $1 \mathrm{~h}$ heating. In accord with the increased activity with number of electron withdrawing substituents, ortho-dichlorobenzene was a 
more receptive substrate ( $27 \%$ total (ca. $26: 1 \mathrm{ClC}_{6} \mathrm{H}_{5}: \mathrm{C}_{6} \mathrm{H}_{6}$ ), Table 4 entry 14 ) than the metadichlorobenzene (19\% total (ca. 18:1 $\left.\mathrm{ClC}_{6} \mathrm{H}_{5}: \mathrm{C}_{6} \mathrm{H}_{6}\right)$, Table 4 entry 15$)$ which, in turn, was better than chlorobenzene ( $8 \%$, entry 3$)$. Finally, it was found that 1-OMe was an excellent catalyst for HDH reactions with a polyaromatic bromides (entries 16-18), heterocyclic 2-bromopyridine (entry 19), and was especially potent for transformations of benzyl bromide and 1-bromooctane (entries 20 and 21).

Table 4. Summary of catalytic hydrodehalogenation reactions of aryl and alkyl halides[ $[\underline{a}]$

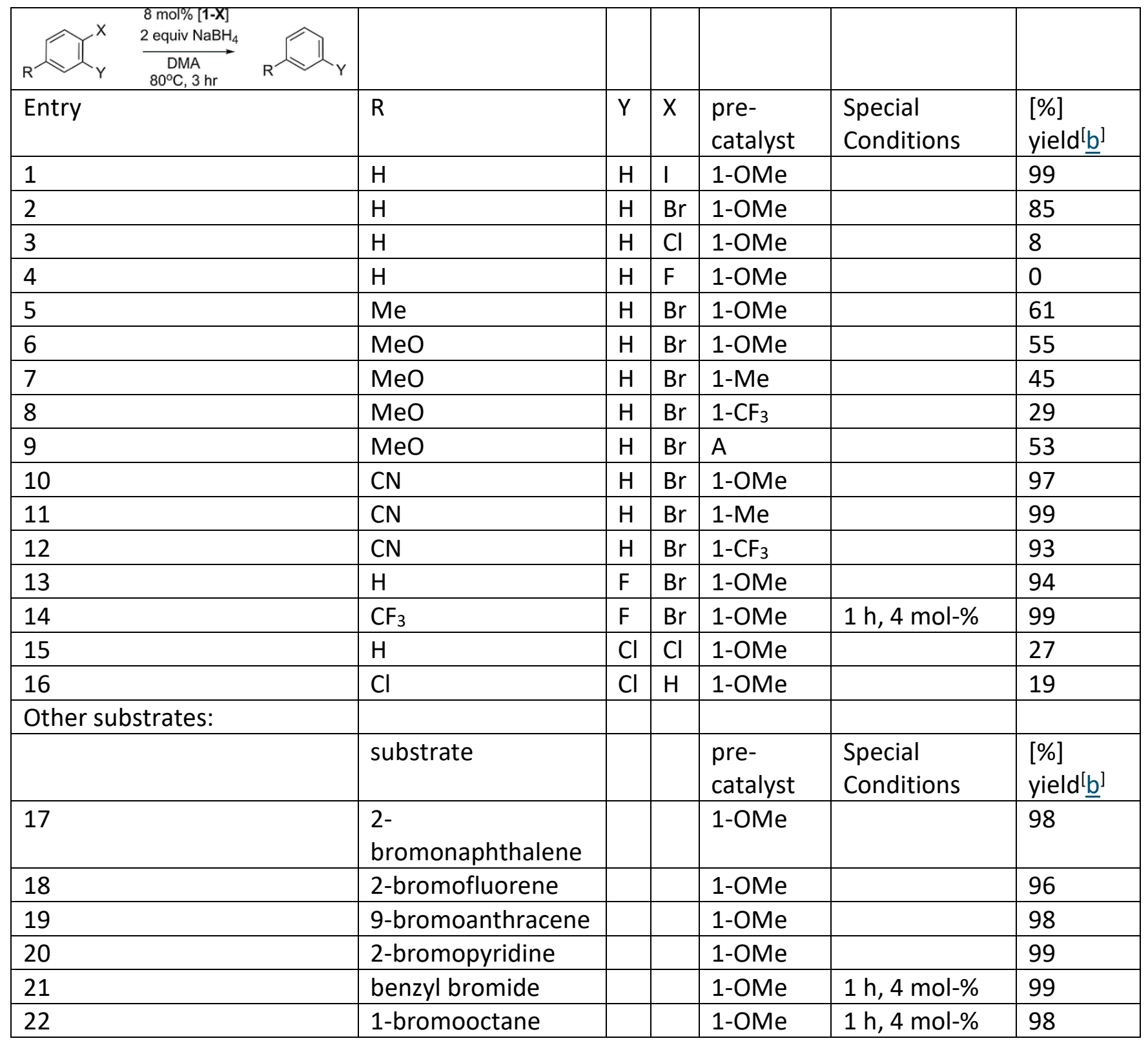

a Reaction scale: $0.2 \mathrm{mmol}$ of organic halide, $0.016 \mathrm{mmol}$ of Ni catalyst ( $8 \mathrm{~mol}-\%$ ) (or $0.008 \mathrm{mmol}, 4 \mathrm{~mol}-\%$, if specified), $\mathrm{NaBH}_{4}\left(15.0 \mathrm{mg}, 0.4 \mathrm{mmol}, 2.0\right.$ equiv.) and $2 \mathrm{~mL}$ dimethylacetamide (DMA), $80^{\circ} \mathrm{C} 3 \mathrm{~h}$ (unless specified).

${ }^{\mathrm{b}} \mathrm{GC} / \mathrm{MS}$ yield, average of three experiments, error $\pm 3 \% \cdots$.

While detailed experimental and computational analysis of reaction kinetics will be the subject of a future report, some plausible mechanistic pathways can be envisioned based on previous proposals 
with similar compounds $\underline{[16-\underline{20]}}$ and on the current results. Scheme $\underline{\mathbf{2}}$ and Figure S28 give some possible mechanisms. The first step (step $A$ ) in any of the paths is the reaction between 1-X and $\mathrm{NaBH}_{4}$ to give the $(\mathrm{PNN}-\mathrm{X}) \mathrm{NiH}$ intermediates, $2-\mathrm{X}\left(\mathrm{X}=\mathrm{OMe}, \mathrm{Me}, \mathrm{CF}_{3}\right)$. Given the reported propensity for $1^{\text {st }}$ row transition metals to be involved in single-electron transfer (SET) chemistry, the previous observations of the hemilability of the current ligand, and the observed trends with electronic effects in the catalysis we currently favor the pathway that includes steps $A-C$, as outlined in the top of Scheme $\underline{2}$. That is, 2$X$, could undergo homolytic cleavage to give ( $P N N-X) N^{1}, 3-X$, and hydrogen, as hypothesized for other hydridonickel(II) (ZNN) pincer complexes $\left.(Z=N, \underline{16}, \underline{18}, \underline{19}] C^{[20]}\right)$, and as supported by the observation of $\mathrm{H}_{2}$ in the NMR spectra during reaction monitoring. Such dissociation may be favored for more electron rich ligands as suggested by DFT calculated $\mathrm{Ni}-\mathrm{H}$ stretching frequencies $(1857,1861$, and $1874 \mathrm{~cm}-1$ for 2-OMe, 2-Me, and 2-OMe, respectively). In the ensuing step B, the 3-X intermediate would presumably undergo oxidative addition (OA) to aryl halide or 1-bromooctane, by an SET pathway to produce a species with the composition ( $\mathrm{PNN}-\mathrm{X}) \mathrm{Ni}(\mathrm{R})(\mathrm{Br}), 4-\mathrm{X}$. Intermediate 4-X, would likely be tetracoordinated nickel(II) bound to a $\mathrm{K}^{2}$-ligand radical (to give a 16 e-complex) due to internal electron transfer from the ligand to the presumptive highly oxidizing nickel(III) center and pyrazolyl- arm dissociation. This step B would also be favored for more electron rich groups. This latter step rather than step $A$ is thought to be the rate-limiting step given the lack of strong kinetic isotope effect (KIE, vide infra) for reactions involving deuteride, and the variable rates of reaction with changing organohalide or para-aryl substituents. In a subsequent step $\mathrm{C}, \mathrm{NaBH}_{4}$ would transfer a hydride to 4$X$ to give $\left(\mathrm{PNN}-\mathrm{X}^{++}\right) \mathrm{Ni}^{\prime \prime}(\mathrm{R})(\mathrm{H}), 5-\mathrm{X}$. Reductive elimination would give formally a nickel(0) bound to a ligand cation radical which would immediately reorganize to the nickel(I) pincer, 3-X. An alternate pathway is possible where ( $\mathrm{PNN}-\mathrm{X}) \mathrm{Ni}(\mathrm{R}), 6-\mathrm{X}$, and a bromo radical are produced by OA between 3$\mathrm{X}$ and organo bromide (perhaps also via dissociation of $4-\mathrm{X}$ ). The bromo radical could abstract a proton from solvent to generate $\mathrm{HBr}$. Any $\mathrm{HBr}$ present would then react with (PNN)NiR to give the dehalogenated organic product and (PNN-X)NiBr. Compound 2-X would be regenerated by reaction with $\mathrm{NaBH}_{4}$. This alternate mechanism was excluded on the basis of deuterium labeling studies described in the next section. The possibility of a $\mathrm{Ni}(\mathrm{II}) / \mathrm{Ni}(0)$ cycle is described in the Supporting information, but such a cycle does not have literature precedence and the heterolytic cleavage of the $\mathrm{Ni}-\mathrm{H}$ bond in 2-X appears less likely than homolytic cleavage.

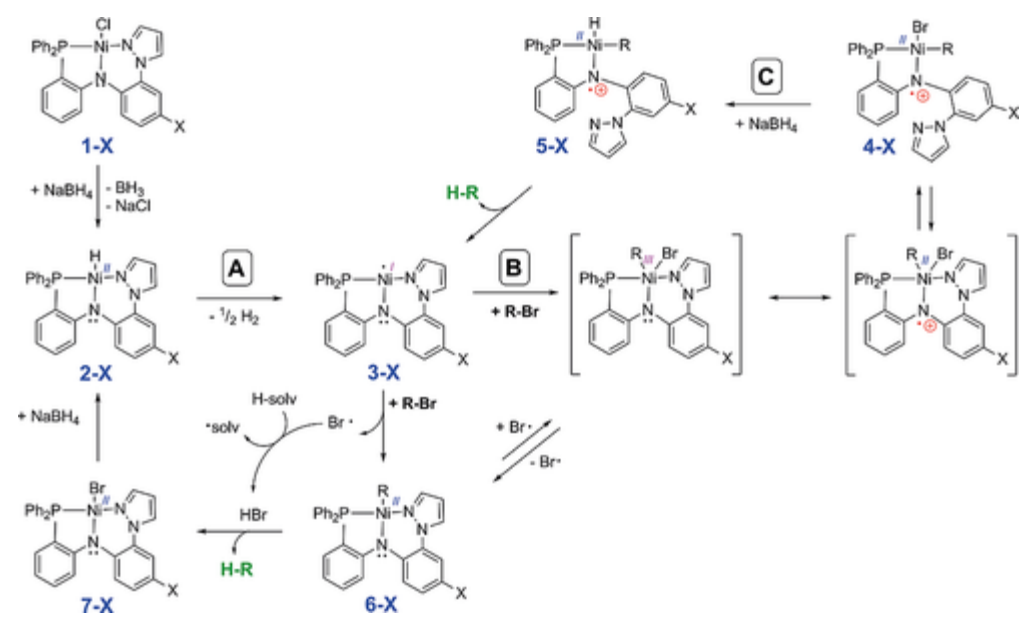

Scheme 2 Potential mechanisms for hydrodehalogentation reactions of organic halides (R-X) catalyzed by [PNN]Ni pincer complexes. 
Several experiments were performed to address the above possibilities. First, it was possible to generate unstable orange-red ( $\mathrm{PNN}-\mathrm{X}) \mathrm{NiH}$ intermediates, $2-\mathrm{X}$, via the reaction between green 1-X and either $\mathrm{NaBH}_{4}$ in THF or NaHBEt 3 in THF/benzene mixtures (Supporting Information). The hydrides decompose to small amounts of $\mathrm{H}_{2}$ gas $\left(\delta_{H}=4.47 \mathrm{ppm}, \mathrm{C}_{6} \mathrm{D}_{6}\right)$, free ligand, and an unidentified brown black paramagnetic species (presumably Ni metal and other species) over the course of a couple hours at room temperature. Freshly prepared samples of 2-X give characteristic hydride doublet resonances at $\delta_{H}=-20.6\left({ }^{2} J_{H P}=109 \mathrm{~Hz}\right),-20.7\left({ }^{2} J_{H P}=110.0 \mathrm{~Hz}\right)$, and $-20.9\left({ }^{2} J_{H P}=112 \mathrm{~Hz}\right) \mathrm{ppm}$ with corresponding doublet ${ }^{31} \mathrm{P} N M R$ resonances at $\delta_{\mathrm{P}}=44.7,44.6,44.1 \mathrm{ppm}$ for 2-OMe, 2-Me, and 2-CF3, respectively. Appropriately, the ${ }^{1} \mathrm{H}$ NMR resonances for $2-X$ are in between those reported for Liang's [PNP-(o$\left.\left.\mathrm{PPh}_{2} \mathrm{C}_{6} \mathrm{H}_{4}\right)_{2} \mathrm{~N}\right] \mathrm{NiH}\left(\delta_{\mathrm{H}}=-18.3 \mathrm{ppm}\right)^{[42]}$ and Hu's [NNN]NiH $\left(\delta_{\mathrm{H}}=-22.8 \mathrm{ppm}\right) . \underline{[16]}$ Moreover, the $\mathrm{Ni}-\mathrm{H}$ stretch was observed by IR spectroscopy at $\mathrm{V}_{\mathrm{NiH}}(\mathrm{THF})=1852,1853$, and $1855 \mathrm{~cm}^{-1}$, for 2-OMe, 2-Me, and $2-\mathrm{CF}_{3}$, respectively. These frequencies are similar to Sun's [CNN]NiH $\left(\mathrm{v}_{\mathrm{NiH}}=1894 \mathrm{~cm}^{-1}\right)^{[20]}$ derived from compound D (Scheme 1) or Lutz's [NNN]NiH (from compound B, Scheme 1; $v_{\mathrm{NiH}}=1858 \mathrm{~cm}^{-}$ ${ }^{1}{ }^{[18]}$ but higher energy than Hu's [NNN] $\left.\mathrm{NiH}\left(\mathrm{v}_{\mathrm{NiH}}=1768 \mathrm{~cm}^{-1}\right) . \underline{16}\right] \mathrm{Next}$, in the presence of TEMPO, no reaction occurred. This result was not particularly informative as it only indicates that TEMPO reacts irreversibly with a reactive intermediate. Therefore, deuterium-labeling studies were investigated. In the reaction of 4-bromobiphenyl with $\mathrm{NaBD}_{4}$ and 8 mol-\% 1-OMe $\left(3 \mathrm{~h} 80^{\circ} \mathrm{C}\right.$ ) $81 \%$ yield (implying KIE $\geq$ 1.2 by comparison with Table $\underline{3}$, entry 1 ) of $4-d_{1}$-biphenyl as the only product, as indicated by its mass spectrum and NMR data. If a solvent-assisted radical pathway were operative one might expect a majority of fully hydrogenated biphenyl. A similar reaction in DMF gave $59 \%$ 4-d d $_{1}$-biphenyl (implying $\mathrm{KIE}=1.3$ by comparison with Table $\underline{3}$, entry 19 ) and $41 \%$ unreacted bromobiphenyl as the only products (Figure S22). The reaction of $\mathrm{NaBH}_{4}$ in $\left[\mathrm{D}_{7}\right] \mathrm{DMF}$ neither showed an isotope effect nor gave deuterium incorporation. Thus, the path involving solvent radicals is excluded. Regardless, it is evident that the non-innocence (redox or chemical) of the pincer ligand plays a crucial role in the catalytic activity. The strategy of decorating diarylamido-based pincer ligands with electron donor groups to improve the hydrodehalogenation activity may be general to nickel pincer complexes of all donor types.

\section{Conclusion}

Three new chloronickel(II) complexes of PNN-pincer ligands have been prepared and shown to be excellent pre-catalysts for the hydrodehalogenation of aryl iodides, as well as aryl and alkyl bromides by employing $\mathrm{NaBH}_{4}$ as a hydride source. The catalytic activity towards aryl chlorides is significantly lower than the bromides but increased with more electron withdrawing substituents in the aryl ring. Deuterium labeling studies demonstrated that $\mathrm{NaBH}_{4}$ is the sole hydride source, and the involvement of solvent radicals could be excluded. Substitution at the pincer ligand para-aniline position with electron donating groups leads to an increase in reactivity due to the increased basicity of the diarylamido nitrogen lone pair. Further substitutions may allow for improvements in activity toward chloro- or fluoro-aromatics, a direction of current study in our group. 


\section{Experimental Section}

\section{Experimental Details.}

Syntheses.

General Considerations.

Chemicals. Solvents for syntheses, spectroscopic characterization or electrochemical studies were dried by conventional means and distilled under Argon prior to use. Solvents used in organic workup or chromatographic separations were used as received from commercial sources. The compound H(PNN) was prepared by the literature method. ${ }^{[30]}$ All other chemicals were used as received from commercial sources. The new ligands $\mathrm{H}(\mathrm{PNN}-\mathrm{OMe})$ and $\mathrm{H}\left(\mathrm{PNN}-\mathrm{CF}_{3}\right)$ were prepared according to the procedures outlined in the Supporting Information.

Instrumentation and characterization. Melting point determinations were made on samples contained in glass capillaries using an Electrothermal 9100 apparatus and are uncorrected. Midwest MicroLab, LLC, Indianapolis, Indiana 45250, performed all elemental analyses. ${ }^{1} \mathrm{H},{ }^{13} \mathrm{C},{ }^{19} \mathrm{~F}$, and ${ }^{31} \mathrm{P} N M R$ spectra were recorded on either a Varian 300 or $400 \mathrm{MHz}$ spectrometer. Chemical shifts were referenced to solvent resonances at $\delta_{H}=7.26$ and $\delta_{C}=77.23$ for $\mathrm{CDCl}_{3}$ or to external references $85 \% \mathrm{H}_{3} \mathrm{PO}_{4}$ (aq.) $\delta_{\mathrm{P}}=$ 0 and $1.0 \mathrm{M} \mathrm{CF}_{3} \mathrm{CO}_{2} \mathrm{H}$ in $\mathrm{CDCl}_{3}$ at $\delta_{\mathrm{F}}=-78.5 \mathrm{ppm}$. Electronic absorption (UV/Vis/NIR) measurements were made on a Cary 5000 instrument. Abbreviations for NMR and UV/Vis data: br (broad), sh (shoulder), m (multiplet), ps (pseudo-), s (singlet), d (doublet), t (triplet), q (quartet). FTIR spectra were recorded for either solid samples or THF solutions (KBr plates) in the $4000-500 \mathrm{~cm}^{-1}$ region on a Thermo Scientific Nicolet iS5 IR spectrometer equipped with an iD3 Attenuated Total Reflection (ATR) accessory. Electrochemical measurements were collected under a nitrogen atmosphere for samples as $0.1 \mathrm{~mm}$ solutions in $\mathrm{CH}_{2} \mathrm{Cl}_{2}$ with $0.1 \mathrm{M} \mathrm{NBu}_{4} \mathrm{PF}_{6}$ as the supporting electrolyte. $A$ three-electrode cell comprised of an $\mathrm{Ag} / \mathrm{AgCl}$ electrode (separated from the reaction medium with a semipermeable polymer membrane filter), a platinum working electrode, and a glassy carbon counter electrode was used for the voltammetric measurements. Data were collected at scan rates of 50, 100, 200, 300, 400, and $500 \mathrm{mV} / \mathrm{s}$. With this set up, the ferrocene/ferrocenium couple matched the literature value ${ }^{[43}, \underline{44]}$ with $\mathrm{E}_{1 / 2}=+0.52 \mathrm{~V}$ in $\mathrm{CH}_{2} \mathrm{Cl}_{2}$ at a scan rate of $200 \mathrm{mV} / \mathrm{s}$.

Nickel Complexes.

(PNN-OMe)NiCl, 1-Me. A pale green solution of $\mathrm{NiCl}_{2} \cdot 6 \mathrm{H}_{2} \mathrm{O}(0.237 \mathrm{~g}, 1.00 \mathrm{mmol})$ in $4 \mathrm{~mL}$ of methanol was added slowly to a magnetically stirred solution of $\mathrm{H}$ (PNN-OMe) $(0.449 \mathrm{~g}, 1.00 \mathrm{mmol})$ in $4 \mathrm{~mL}$ of dichloromethane, whereupon the solution immediately became darker green. After 5 min of stirring, a solution of tetraethylammonium hydroxide $(0.70 \mathrm{~mL}$ of $1.43 \mathrm{M}$ in methanol, $1.0 \mathrm{mmol}$ ) was added causing copious green precipitate. After, the resulting dark green suspension had been stirred for $3 \mathrm{~h}$, the green solid was collected by filtration. The filtrate was reduced to $3 \mathrm{~mL}$ by rotary evaporation and a second portion of green precipitate was isolated by filtration. The combined green precipitate was rinsed with $3 \mathrm{~mL}$ methanol and then was dried under oil pump vacuum (10-3 Torr) at room temperature $1 \mathrm{~h}$ to give analytically pure 1-OMe $(0.512 \mathrm{mg}$, yield $94 \%)$ as an olive green powder.

$\mathrm{Mp},>260^{\circ} \mathrm{C}$ (dec.). Anal. Calcd. (Found) for $\mathrm{C}_{28} \mathrm{H}_{23} \mathrm{ClN}_{3} \mathrm{ONiP}: \mathrm{C}, 61.98$ (62.12); H, 4.27 (4.27); N, 7.74 (7.50). ${ }^{1} \mathrm{H}$ NMR (400 MHz, $\left.\mathrm{CDCl}_{3}\right) \delta_{\mathrm{H}}=8.12\left(\mathrm{~s}, 1 \mathrm{H}, \mathrm{H}_{5}-\mathrm{pz}\right), 7.99\left(\mathrm{~s}, 1 \mathrm{H}, \mathrm{H}_{3}-\mathrm{pz}\right), 7.98\left(\mathrm{~m}, 2 \mathrm{H}, o-\mathrm{PPh}_{2}{ }^{\mathrm{B}}\right)$, $7.87\left(\mathrm{~m}, 2 \mathrm{H}, \mathrm{o}-\mathrm{PPh}_{2}{ }^{\mathrm{A}}\right), 7.55-7.40\left(\mathrm{~m}, 6 \mathrm{H}, \mathrm{m}-+\right.$ p-PPh $\left._{2}\right), 7.34$ (d, J = 9.0 Hz, $1 \mathrm{H}, \mathrm{H}_{6}$-tolyl), 7.05-7.01 (m, $3 \mathrm{H}, \mathrm{H}_{4-}, \mathrm{H}_{5^{-}}$, and $\left.\mathrm{H}_{6}-\mathrm{C}_{6} \mathrm{H}_{4}\right), 6.69\left(\mathrm{~d}, J=2.8 \mathrm{~Hz}, 1 \mathrm{H}, \mathrm{H}_{3}\right.$-tolyl), 6.62 (d, J = 9.0, $2.8 \mathrm{~Hz}, 1 \mathrm{H}, \mathrm{H}_{5}$-tolyl), 6.58 
$\left(\mathrm{m}, 1 \mathrm{H}, \mathrm{H}_{4}-\mathrm{pz}\right), 6.54\left(\mathrm{~m}, \mathrm{H}_{3}-\mathrm{C}_{6} \mathrm{H}_{4}\right), 3.78\left(\mathrm{~s}, 3 \mathrm{H}, \mathrm{OCH}_{3}\right)$ ppm. ${ }^{13} \mathrm{C} \mathrm{NMR}\left(101.52 \mathrm{MHz}, \mathrm{CDCl}_{3}\right) \delta_{\mathrm{c}}:=162.90$ $\left(\mathrm{d},{ }^{2} \mathrm{~J}_{\mathrm{C}-\mathrm{P}}=26.1 \mathrm{~Hz}, \mathrm{C}_{2}-\mathrm{C}_{6} \mathrm{H}_{4}\right.$ ), 153.07 (s, $\mathrm{C}_{4}$-tolyl), 142.89 (s, $\mathrm{C}_{5}-\mathrm{pz}$ ), 137.61 (s, $\mathrm{C}_{1}$-tolyl), 133.98 (d, ${ }^{2} \mathrm{~J}_{\mathrm{C}-\mathrm{P}}=$ $\left.10.3 \mathrm{~Hz}, 0-\mathrm{PPh}_{2}{ }^{\mathrm{A}}\right), 133.10\left(\mathrm{~s}, \mathrm{C}_{6}-\mathrm{C}_{6} \mathrm{H}_{4}\right), 132.90\left(\mathrm{~d},{ }^{2} \mathrm{~J}_{\mathrm{C}-\mathrm{P}}=10.4 \mathrm{~Hz}, o-\mathrm{PPh}_{2}{ }^{\mathrm{B}}\right), 132.35\left(\mathrm{~d},{ }^{4} \mathrm{~J}_{C-P}=1.9 \mathrm{~Hz}, \mathrm{C}_{4^{-}}\right.$ $\left.\mathrm{C}_{6} \mathrm{H}_{4}\right), 131.80\left(\mathrm{C}_{2}\right.$-tolyl), $131.50\left(\mathrm{~d},{ }^{4} J_{C-P}=2.5 \mathrm{~Hz}, p-\mathrm{PPh}_{2}{ }^{\mathrm{A}}\right), 131.13\left(\mathrm{~d},{ }^{4} J_{C-P}=2.4 \mathrm{~Hz}, p-\mathrm{PPh}_{2}{ }^{\mathrm{B}}\right), 129.45$ $\left(d,{ }^{1} J_{C-P}=47.1 \mathrm{~Hz}\right.$, ipso-PPh $\left.{ }^{\mathrm{B}}\right), 129.25\left(\mathrm{~d},{ }^{1} J_{C-P}=59.1 \mathrm{~Hz}\right.$, ipso-PPh $\left.{ }^{\mathrm{A}}\right), 129.13\left(\mathrm{~d},{ }^{3} J_{C-P}=10.7 \mathrm{~Hz}, m-\mathrm{PPh}_{2}{ }^{\mathrm{A}}\right)$, $128.70\left(\mathrm{~d},{ }^{3} J_{C-P}=11.4 \mathrm{~Hz}, m-\mathrm{PPh}_{2}{ }^{\mathrm{B}}\right.$ ), $128.59\left(\mathrm{~d},{ }^{3} \mathrm{~J}_{\mathrm{C}-\mathrm{P}}=2.2 \mathrm{~Hz}, \mathrm{C}_{3}-\mathrm{pz}\right), 123.89$ (s, $\mathrm{C}_{6}$-tolyl), $123.00\left(\mathrm{~d},{ }^{1} J_{C_{-}-P}=\right.$ $\left.54.7 \mathrm{~Hz}, \mathrm{C}_{1}-\mathrm{C}_{6} \mathrm{H}_{4}\right), 120.63\left(\mathrm{~d},{ }^{3} \mathrm{~J}_{\mathrm{C}-\mathrm{P}}=11.7 \mathrm{~Hz}, \mathrm{C}_{5}-\mathrm{C}_{6} \mathrm{H}_{4}\right), 118.54\left(\mathrm{~d},{ }^{3} \mathrm{~J}_{--P}=7.3 \mathrm{~Hz}, \mathrm{C}_{3}-\mathrm{C}_{6} \mathrm{H}_{4}\right), 114.20\left(\mathrm{~s}, \mathrm{C}_{5}-\right.$ tolyl), $108.68\left(\mathrm{~d},{ }^{4} \mathrm{~J}_{\mathrm{C}-\mathrm{P}}=1.6 \mathrm{~Hz}, \mathrm{C}_{4}-\mathrm{pz}\right), 107.94$ (s, $\mathrm{C}_{3}$-tolyl), $56.08\left(\mathrm{OCH}_{3}\right)$ ppm. ${ }^{31} \mathrm{P} \mathrm{NMR}\left(162 \mathrm{MHz}, \mathrm{CDCl}_{3}\right)$ $\delta_{p}=30.59(\mathrm{~s}) \mathrm{ppm}$.

Crystals of 1-OMe were grown by vapor diffusion of pentane into a solution of $30 \mathrm{mg} 1-\mathrm{OMe}$ in $2 \mathrm{~mL}$ $\mathrm{C}_{6} \mathrm{H}_{6}$.

(PNN-Me)NiCl, 1-Me. In a manner identical to the above, $0.237 \mathrm{~g}(1.00 \mathrm{mmol}) \mathrm{NiCl}_{2} \cdot 6 \mathrm{H}_{2} \mathrm{O}$ in $5 \mathrm{~mL}$ of methanol, $0.433 \mathrm{~g} \mathrm{H}(\mathrm{PNN}-\mathrm{Me})(1.00 \mathrm{mmol})$ in $5 \mathrm{~mL}$ of dichloromethane, and $0.70 \mathrm{~mL}$ of $1.43 \mathrm{M} \mathrm{NEt}_{4}(\mathrm{OH})$ in methanol $(1.0 \mathrm{mmol})$ gave $0.478 \mathrm{~g}$ (91\% yield) 1-Me as a green powder.

$\mathrm{Mp},>260{ }^{\circ} \mathrm{C}$ (dec.). Anal. Calcd. (Found) for $\mathrm{C}_{28} \mathrm{H}_{23} \mathrm{CIN}_{3} \mathrm{NiP}: \mathrm{C}, 63.86$ (63.64); $\mathrm{H}, 4.40$ (4.77); N, 7.80 (8.00). ${ }^{1} \mathrm{H} N M R\left(400 \mathrm{MHz}, \mathrm{CDCl}_{3}\right) \delta_{\mathrm{H}}=8.11\left(\mathrm{~s}, 1 \mathrm{H}, \mathrm{H}_{5}-\mathrm{pz}\right), 8.00\left(\mathrm{~s}, 1 \mathrm{H}, \mathrm{H}_{3}-\mathrm{pz}\right), 7.96\left(\mathrm{~m}, 2 \mathrm{H}, o-\mathrm{PPh}_{2}{ }^{\mathrm{B}}\right)$, $7.87\left(\mathrm{~m}, 2 \mathrm{H}, o-\mathrm{PPh}_{2}{ }^{\mathrm{A}}\right), 7.55-7.49\left(\mathrm{~m}, 2 \mathrm{H}, p-\mathrm{PPh}_{2}\right), 7.49-7.39\left(\mathrm{~m}, 4 \mathrm{H}, m-\mathrm{PPh}_{2}\right), 7.34(\mathrm{~d}, J=8.5 \mathrm{~Hz}, 1 \mathrm{H}$, $\mathrm{H}_{6}$-tolyl), 7.07-6.97 (m, $3 \mathrm{H}, \mathrm{C}_{6} \mathrm{H}_{4}$ ), 6.96 (s, $1 \mathrm{H}, \mathrm{H}_{3}$-tolyl), 6.81 (d, J = 8.5 Hz, $1 \mathrm{H}, \mathrm{H}_{5}$-tolyl), 6.57 (br m, 2 $\left.\mathrm{H}, \mathrm{H}_{3}-\mathrm{C}_{6} \mathrm{H}_{4}+\mathrm{H}_{4}-\mathrm{pz}\right), 2.25\left(\mathrm{~s}, 3 \mathrm{H}, \mathrm{CH}_{3}\right)$ ppm. ${ }^{13} \mathrm{C} \mathrm{NMR}\left(101.52 \mathrm{MHz}, \mathrm{CDCl}_{3}\right) \delta_{c}:=162.83\left(\mathrm{~d},{ }^{2} J_{c-p}=25.7 \mathrm{~Hz}\right.$, $\left.\mathrm{C}_{2}-\mathrm{C}_{6} \mathrm{H}_{4}\right), 142.59$ (s, $\left.\mathrm{C}_{5}-\mathrm{pz}\right), 141.63$ (s, $\mathrm{C}_{1}$-tolyl), 133.98 (d, $\left.{ }^{2} \mathrm{~J}_{\mathrm{C}-\mathrm{P}}=10.4 \mathrm{~Hz}, o-\mathrm{PPh}_{2}{ }^{\mathrm{A}}\right), 133.03\left(\mathrm{~s}, \mathrm{C}_{6}-\mathrm{C}_{6} \mathrm{H}_{4}\right)$, $132.87\left(\mathrm{~d},{ }^{2} J_{C-P}=10.3 \mathrm{~Hz}, o-P P h_{2}{ }^{B}\right), 132.29\left(\mathrm{~d},{ }^{4} J_{C-P}=2.1 \mathrm{~Hz}, p-P P h_{2}{ }^{B}\right), 132.15\left(\mathrm{~d},{ }^{4} J_{C-P}=2.1 \mathrm{~Hz}, \mathrm{C}_{4}-\mathrm{C}_{6} \mathrm{H}_{4}\right)$, $131.22\left(C_{2}\right.$-tolyl), $131.12\left(\mathrm{~d},{ }^{4} J_{C-P}=2.1 \mathrm{~Hz}, p-\mathrm{PPh}_{2}{ }^{\mathrm{A}}\right), 129.38\left(\mathrm{~d},{ }^{1} J_{C_{-}-P}=50.2 \mathrm{~Hz}\right.$, ipso-PPh $\left.{ }^{\mathrm{A}}\right), 129.26\left(\mathrm{~d},{ }^{1} J_{C_{-}}\right.$ $P=47.0 \mathrm{~Hz}$, ipso-PPh${ }_{2}{ }^{\mathrm{B}}$ ), $129.12\left(\mathrm{~d},{ }^{3} \mathrm{~J}_{\mathrm{C}-P}=10.4 \mathrm{~Hz}, m-\mathrm{PPh}_{2}{ }^{\mathrm{B}}\right.$ ), 129.09 (s, $\mathrm{C}_{5}$-tolyl), 128.91 (s, $\mathrm{C}_{4}$-tolyl), $128.69\left(\mathrm{~d},{ }^{3} J_{C-P}=11.7 \mathrm{~Hz}, m-\mathrm{PPh}_{2}{ }^{\mathrm{A}}\right), 128.48\left(\mathrm{~d},{ }^{3} J_{C-P}=2.1 \mathrm{~Hz}, \mathrm{C}_{3}-\mathrm{pz}\right), 123.34\left(\mathrm{~d},{ }^{1} J_{C-P}=54.4 \mathrm{~Hz}, \mathrm{C}_{1}-\mathrm{C}_{6} \mathrm{H}_{4}\right)$, 122.75 (s, $\mathrm{C}_{3}$-tolyl), 122.73 (s, $\mathrm{C}_{6}$-tolyl), 120.98 (d, ${ }^{3} \mathrm{~J}_{C-P}=11.7 \mathrm{~Hz}, \mathrm{C}_{5}-\mathrm{C}_{6} \mathrm{H}_{4}$ ), $118.82\left(\mathrm{~d},{ }^{3} \mathrm{~J}_{C-P}=7.2 \mathrm{~Hz}, \mathrm{C}_{3}-\right.$ $\left.\mathrm{C}_{6} \mathrm{H}_{4}\right), 108.48\left(\mathrm{~d},{ }^{4} J_{\mathrm{C}-\mathrm{p}}=1.6 \mathrm{~Hz}, \mathrm{C}_{4}-\mathrm{pz}\right), 20.84\left(\mathrm{CH}_{3}\right) \mathrm{ppm} .{ }^{31} \mathrm{P} \mathrm{NMR}\left(162 \mathrm{MHz}, \mathrm{CDCl}_{3}\right) \delta_{\mathrm{p}}=30.32$ (s) ppm. FTIR ( $\mathrm{cm}^{-1}$; solid): 3114 (w), 3047 (w), 2863 (w), 1579 (s), 1500 (s), 1456 (s), 1434 (s), 1290 (s).

Crystals of 1-Me were grown by vapor diffusion of $\mathrm{Et}_{2} \mathrm{O}$ into a solution of $30 \mathrm{mg}$ 1-Me in $3 \mathrm{~mL} \mathrm{C}_{6} \mathrm{H}_{6}$.

$\left(\mathrm{PNN}_{-} \mathrm{CF}_{3}\right) \mathrm{NiCl}, 1-\mathrm{CF}_{3}$. In a manner identical to the above, $0.237 \mathrm{~g}(1.00 \mathrm{mmol}) \mathrm{NiCl}_{2} \cdot 6 \mathrm{H}_{2} \mathrm{O}$ in $4 \mathrm{~mL}$ of methanol, $0.487 \mathrm{~g} \mathrm{H}\left(\mathrm{PNN}^{\left.-\mathrm{CF}_{3}\right)}(1.00 \mathrm{mmol})\right.$ in $4 \mathrm{~mL}$ of dichloromethane, and $0.70 \mathrm{~mL}$ of $1.43 \mathrm{M} \mathrm{NEt}_{4}(\mathrm{OH})$ in methanol $(1.0 \mathrm{mmol})$ gave $0.541 \mathrm{~g}$ (94\% yield) $1-\mathrm{CF}_{3}$ as a teal green powder.

$\mathrm{Mp},>260^{\circ} \mathrm{C}$ (dec.). Anal. Calcd. (Found) for $\mathrm{C}_{28} \mathrm{H}_{20} \mathrm{ClF}_{3} \mathrm{~N}_{3} \mathrm{NiP}: \mathrm{C}, 57.92$ (57.52); H, 3.47 (3.73); N, 7.24 (7.18). ${ }^{1} \mathrm{H} N M R\left(400 \mathrm{MHz}, \mathrm{CDCl}_{3}\right) \delta_{\mathrm{H}}=8.14\left(\mathrm{~s}, 1 \mathrm{H}, \mathrm{H}_{5}-\mathrm{pz}\right), 8.07\left(\mathrm{~s}, 1 \mathrm{H}, \mathrm{H}_{3}-\mathrm{pz}\right), 7.95$ (dd, J= 11.4, 7.9 Hz, $\left.2 \mathrm{H}, o-\mathrm{PPh}_{2}{ }^{\mathrm{B}}\right), 7.86\left(\mathrm{dd}, J=12.2,7.9 \mathrm{~Hz}, 2 \mathrm{H}, \mathrm{o}-\mathrm{PPh}_{2}{ }^{\mathrm{A}}\right), 7.58-7.51\left(\mathrm{~m}, 2 \mathrm{H}, p-\mathrm{PPh}_{2}\right), 7.50-7.42(\mathrm{~m}, 4 \mathrm{H}, \mathrm{m}-$ $\mathrm{PPh}_{2}$ ), 7.49 (d, J=8.4 Hz, $1 \mathrm{H}, \mathrm{H}_{6}$-tolyl), 7.39 (s, $1 \mathrm{H}, \mathrm{H}_{3}$-tolyl), 7.18 (d, J = 8.4 Hz, $1 \mathrm{H}, \mathrm{H}_{5}$-tolyl), 7.15$7.05\left(\mathrm{~m}, 3 \mathrm{H}, \mathrm{H}_{4^{-}}, \mathrm{H}_{5^{-}}\right.$, and $\left.\mathrm{H}_{6}-\mathrm{C}_{6} \mathrm{H}_{4}\right), 6.68\left(\mathrm{~m}, 1 \mathrm{H}, \mathrm{H}_{3}-\mathrm{C}_{6} \mathrm{H}_{4}\right), 6.63\left(\mathrm{~m}, 1 \mathrm{H}, \mathrm{H}_{4}-\mathrm{pz}\right) \mathrm{ppm} .{ }^{13} \mathrm{C} \mathrm{NMR}(101.52$ $\mathrm{MHz}, \mathrm{CDCl}_{3}$ ) $\delta_{\mathrm{c}}:=161.94\left(\mathrm{~d},{ }^{2} \mathrm{~J}_{\mathrm{C}-\mathrm{P}}=24.8 \mathrm{~Hz}, \mathrm{C}_{2}-\mathrm{C}_{6} \mathrm{H}_{4}\right.$ ), 143.09 (s, C5-pz), 148.04 (s, $\mathrm{C}_{1}$-tolyl), 134.01 (d, ${ }^{2} \mathrm{~J}_{\mathrm{C}-}$ $\left.p=10.4 \mathrm{~Hz}, o-\mathrm{PPh}_{2}{ }^{\mathrm{A}}\right), 133.17\left(\mathrm{~s}, \mathrm{C}_{6}-\mathrm{C}_{6} \mathrm{H}_{4}\right), 132.86\left(\mathrm{~d},{ }^{2} \mathrm{~J}_{\mathrm{C}-\mathrm{P}}=10.4 \mathrm{~Hz}, o-\mathrm{PPh}_{2}{ }^{\mathrm{B}}\right), 132.63\left(\mathrm{~d},{ }^{4} J_{C-P}=2.2 \mathrm{~Hz}, \mathrm{C}_{4^{-}}\right.$ $\left.\mathrm{C}_{6} \mathrm{H}_{4}\right), 131.45\left(\mathrm{~d},{ }^{4} J_{C-P}=3.0 \mathrm{~Hz}, p-\mathrm{PPh}_{2}{ }^{\mathrm{A}}\right), 131.42\left(\mathrm{~d},{ }^{4} J_{C-P}=3.1 \mathrm{~Hz}, p-\mathrm{PPh}_{2}{ }^{\mathrm{B}}\right), 130.58\left(\mathrm{C}_{2}\right.$-tolyl), 129.31 $\left(d,{ }^{3} J_{C-P}=10.7 \mathrm{~Hz}, m-P_{P h}{ }^{A}\right), 129.00\left(d,{ }^{3} J_{C-P}=1.8 \mathrm{~Hz}, C_{3}-p z\right), 128.83\left(d,{ }^{3} J_{C-P}=11.9 \mathrm{~Hz}, m-P P_{2}{ }^{B}\right), 128.66$ 


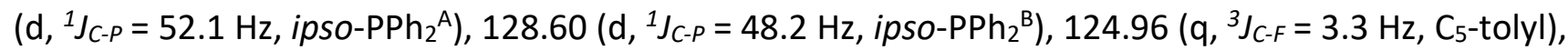
$124.51\left(\mathrm{~d},{ }^{1} J_{C-P}=53.8 \mathrm{~Hz}, \mathrm{C}_{1}-\mathrm{C}_{6} \mathrm{H}_{4}\right), 122.51\left(\mathrm{~s}, \mathrm{C}_{6}\right.$-tolyl), $121.30\left(\mathrm{~d},{ }^{3} \mathrm{~J}_{C-P}=11.5 \mathrm{~Hz}, \mathrm{C}_{5}-\mathrm{C}_{6} \mathrm{H}_{4}\right), 122.16\left(\mathrm{q}^{1},{ }^{1} J_{C-}\right.$ $\left.F=197 \mathrm{~Hz}, \mathrm{CF}_{3}\right), 120.43\left(\mathrm{~d},{ }^{3} \mathrm{~J}_{\mathrm{C}-\mathrm{P}}=7.3 \mathrm{~Hz}, \mathrm{C}_{3}-\mathrm{C}_{6} \mathrm{H}_{4}\right), 120.10\left(\mathrm{q},{ }^{2} \mathrm{~J}_{\mathrm{C}-\mathrm{F}}=33.6 \mathrm{~Hz}, \mathrm{C}_{4}-\mathrm{tolyl}\right), 119.72\left(\mathrm{q},{ }^{3} \mathrm{~J}_{\mathrm{C}-F}=\right.$ $4.0 \mathrm{~Hz}, \mathrm{C}_{3}$-tolyl), $109.12\left(\mathrm{~d},{ }^{4} \mathrm{~J}_{\mathrm{C}-\mathrm{P}}=1.7 \mathrm{~Hz}, \mathrm{C}_{4}-\mathrm{pz}\right.$ ) ppm. ${ }^{31} \mathrm{P} \mathrm{NMR}\left(162 \mathrm{MHz}, \mathrm{CDCl}_{3}\right) \delta_{\mathrm{p}}=29.80$ (s) ppm.

Crystals of 1- $\mathrm{CF}_{3}$ were grown by vapor diffusion of pentane into a solution of $30 \mathrm{mg} 1-\mathrm{CF}_{3}$ in $2 \mathrm{~mL} \mathrm{C}_{6} \mathrm{H}_{6}$. Catalysis.

General Procedure. A $100 \mathrm{~mL}$ round-bottomed flask equipped with a magnetic stir bar was charged with $0.047 \mathrm{~g}(0.20 \mathrm{mmol}$ ) of 4-bromobiphenyl (or $0.20 \mathrm{mmol}$ of another aryl halide), $8.4 \mathrm{mg}$ (0.016 mmol, 8 mol-\%) catalyst 1-X (or other nickel salt) $15 \mathrm{mg}\left(0.40 \mathrm{mmol}, 2.0\right.$ equiv.) of $\mathrm{NaBH}_{4}$ as hydrogen source and $2 \mathrm{~mL}$ of dimethylacetamide (DMA) as solvent under argon atmosphere. Next, the magnetically stirred mixture was heated with $80^{\circ} \mathrm{C}$ oil bath. After $3 \mathrm{~h}$ stirring at $80^{\circ} \mathrm{C}$, the mixture was cooled down and passed through silica gel with rinsing $2 \mathrm{~mL}$ of dichloromethane. Then, 1,4Bis(trimethylsilyl)benzene (11.1 $\mathrm{mg}$ ) was added as an internal standard and the resulting mixture was subjected to GC-MS for the product analysis. The yields of product and unreacted starting material were also calibrated against standard solutions of biphenyl and 4-bromobiphenyl.

Crystallography. X-ray intensity data from a dark green prism of 1-OMe (CCDC 2027563), a green plate ( $P 1$, CCDC 2027564) and a green needle ( $P 2_{1} / n$, CCDC 2027565) of 1-Me, and a green needle of 1$\mathrm{CF}_{3}$ (CCDC 2027566) were collected at 100.0(1) K with an Oxford Diffraction Ltd. Supernova diffractometer equipped with a $135 \mathrm{~mm}$ Atlas $\mathrm{CCD}$ detector. Mo $\left(K_{\alpha}\right)$ radiation was used for the experiments with 1-OMe and monoclinic 1-Me while $\mathrm{Cu}\left(K_{\alpha}\right)$ radiation was used for the other experiments. Raw data frame integration and Lp corrections were performed with CrysAlis Pro (Oxford Diffraction, Ltd.). ${ }^{[45]}$ Final unit cell parameters were determined by least-squares refinement of 12291 , 13164, 10260, and 12849 reflections of 1-OMe, monoclinic 1-Me, triclinic 1-Me, and 1-CF 3 , respectively, with $I>2 \sigma(l)$ for each. Analysis of the data showed negligible crystal decay during collection in each case. Direct methods structure solutions, difference Fourier calculations and fullmatrix least-squares refinements against $F^{2}$ were performed with SHELXTL.[46] Numerical absorption corrections based on Gaussian integration over a multifaceted crystal model were applied to the data in each experiment. All non-hydrogen atoms were refined with anisotropic displacement parameters. Hydrogen atoms were placed in geometrically idealized positions and included as riding atoms. The Xray crystallographic parameters and further details of data collection and structure refinements are given in Table S1.

Computational Details.

DFT calculations were performed using the Minnesota M06 meta-hybrid GGA functional[4ㄱ] because it has been found to be useful for affording accurate solutions to a wide variety of computation problems. Geometry optimizations employed the def2-SV(P) double-zeta basis set ${ }^{[48]}$ because we previously found ${ }^{[34,49]}$ (and find again here) that this method provides excellent agreement (within 0.2 $\AA$ A) with solid-state structures. Solvent (dichloromethane) effects were accounted for by using the polarizable continuum model PCM/UFF, ${ }^{\text {[50] }}$ as implemented in Gaussian $16 .{ }^{[51]}$ Analytical vibrational frequency calculations were carried out to verify that optimized geometries were stationary points. Time-dependent (TD) DFT methodology $[\underline{[52-54]}$ was used for excitation energy calculations of the first 25 excited states. Each excitation was fitted to a Gaussian curve with standard deviation of $\sigma=0.3 \mathrm{eV}$ and 
spectra were calculated by summing individual contributions. Tables S4-S7 summarizes the results of these studies. Cartesian coordinates are contained within the PNNX_NiCl_DFT.xyz file found in the Supporting Information. Reduction potentials were calculated by using the method outlined by Batista $[\underline{[5,}, 56]$ but applying corrections as outlined by Bühl, ${ }^{[57]}$ where the ultimate potential obtained by $-\Delta G^{\circ}$ (red,solv - ox,solv)/F was scaled to the $\mathrm{Ag} / \mathrm{AgCl}$ electrode by subtraction of $4.403 \mathrm{eV}$ (i.e., it was referenced against the absolute SHE potential $\left(\mathrm{CH}_{2} \mathrm{Cl}_{2}\right)$ at $4.60 \mathrm{~V}$ and then to $\mathrm{Ag} / \mathrm{AgCl}+0.197 \mathrm{~V}$ vs. SHE).

Deposition Numbers 2027563, 2027564, 2027565 and 2027566 contain the supplementary crystallographic data for this paper. These data are provided free of charge by the joint Cambridge Crystallographic Data Centre and Fachinformationszentrum Karlsruhe Access Structures service www.ccdc.cam.ac.uk/structures.

\section{Acknowledgements}

JRG thanks the donors of the Petroleum Research Fund (\#58705-ND3) and Marquette University for support. We thank Brandon Kizer for initial work with syntheses and characterization of 1-Me.

\begin{tabular}{|l|l|}
\hline Filename & Description \\
\hline ejic202000721-sup-0001-SupMat.pdf6.4 MB & Supporting Information \\
\hline
\end{tabular}

Please note: The publisher is not responsible for the content or functionality of any supporting information supplied by the authors. Any queries (other than missing content) should be directed to the corresponding author for the article.

\section{References}

1 F. Alonso, I. P. Beletskaya and M. Yus, Chem. Rev, 2002, 102, 4009- 4092.

2 C. Menini, C. Park, E.-J. Shin, G. Tavoularis and M. A. Keane, Catal. Today, 2000, 62, 355- 366.

3 G. Chelucci, S. Baldino, G. A. Pinna and G. Pinna, Curr. Org. Chem, 2012, 16, 2921- 2945.

4 V. D. Shteingarts, J. Fluorine Chem, 2007, 128, 797- 805.

5 M. Hu, Y. Liu, Z. Yao, L. Ma and X. Wang, Front. Environ. Sci. Eng, 2017, 12, 3.

6 J. Ke, H. Wang, L. Zhou, C. Mou, J. Zhang, L. Pan and Y. R. Chi, Chem. Eur. J, 2019, 25, 6911- 6914.

7 C. Lei, F. Liang, J. Li, W. Chen and B. Huang, Chem. Eng. J, 2019, 358, 1054- 1064.

8 V. Agarwal, Z. D. Miles, J. M. Winter, A. S. Eustáquio, A. A. El Gamal and B. S. Moore, Chem. Rev, 2017, 117, 5619- 5674.

9 R. F. Howe, Appl. Catal. A, 2004, 271, 3- 11.

10 Y. Wang, Y. Wei, W. Song, C. Chen and J. Zhao, ChemCatChem, 2019, 11, 258- 268.

11 Z.-Z. Zhou, J.-H. Zhao, X.-Y. Gou, X.-M. Chen and Y.-M. Liang, Org. Chem. Front, 2019, 6, 1649- 1654.

12 T.-H. Ding, J.-P. Qu and Y.-B. Kang, Org. Lett, 2020, 22, 3084- 3088.

13 K. V. Murthy, P. M. Patterson and M. A. Keane, J. Mol. Catal. A, 2005, 225, 149- 160.

14 A. Scrivanti, B. Vicentini, V. Beghetto, G. Chessa and U. Matteoli, Inorg. Chem. Commun, 1998, 1, 246- 248.

15 C. J. E. Davies, M. J. Page, C. E. Ellul, M. F. Mahon and M. K. Whittlesey, Chem. Commun, 2010, 46, 5151- 5153.

16 J. Breitenfeld, R. Scopelliti and X. Hu, Organometallics, 2012, 31, 2128- 2136.

17 M. Weidauer, E. Irran, C. I. Someya, M. Haberberger and S. Enthaler, J. Organomet. Chem, 2013, 729, 53- 59. 
18 C. Rettenmeier, H. Wadepohl and L. H. Gade, Chem. Eur. J, 2014, 20, 9657- 9665.

19 C. A. Rettenmeier, J. Wenz, H. Wadepohl and L. H. Gade, Inorg. Chem, 2016, 55, 8214- 8224.

20 Z. Wang, X. Li, H. Sun, O. Fuhr and D. Fenske, Organometallics, 2018, 37, 539- 544.

21 C. Yao, S. Wang, J. Norton and M. Hammond, J. Am. Chem. Soc, 2020, 142, 4793- 4799.

22 R. Shi, Z. Zhang and X. Hu, Acc. Chem. Res, 2019, 52, 1471- 1483.

23 Y.-P. Zhang, M. Zhang, X.-R. Chen, C. Lu, D. J. Young, Z.-G. Ren and J.-P. Lang, Inorg.

Chem, 2020, 59, 1038- 1045.

24 D. Wu and Z.-X. Wang, Org. Biomol. Chem, 2014, 12, 6414- 6424.

25 Y. Kim, J. Lee, Y.-H. Son, S.-U. Choi, M. Alam and S. Park, J. Inorg. Biochem, 2020, 205, 111015.

26 S. Das, V. Subramaniyan and G. Mani, Inorg. Chem, 2019, 58, 3444- 3456.

27 X. Yang and Z.-X. Wang, Organometallics, 2014, 33, 5863- 5873.

28 L.-C. Liang, W.-Y. Lee, Y.-T. Hung, Y.-C. Hsiao, L.-C. Cheng and W.-C. Chen, Dalton

Trans, 2012, 41, 1381- 1388.

29 C. P. Yap, Y. Y. Chong, T. S. Chwee and W. Y. Fan, Dalton Trans, 2018, 47, 8483- 8488.

30 S. Wanniarachchi, J. S. Hewage, S. V. Lindeman and J. R.

Gardinier, Organometallics, 2013, 32, 2885- 2888.

31 B. J. Liddle, R. M. Silva, T. J. Morin, F. P. Macedo, R. Shukla, S. V. Lindeman and J. R. Gardinier, J. Org. Chem, 2007, 72, 5637- 5646.

32 L.-C. Liang, P.-S. Chien, J.-M. Lin, M.-H. Huang, Y.-L. Huang and J.-H.

Liao, Organometallics, 2006, 25, 1399- 1411.

33 S. Lapointe, E. Khaskin, R. R. Fayzullin and J. R.

Khusnutdinova, Organometallics, 2019, 38, 1581- 1594.

34 J. S. Hewage, S. Wanniarachchi, T. J. Morin, B. J. Liddle, M. Banaszynski, S. V. Lindeman, B.

Bennett and J. R. Gardinier, Inorg. Chem, 2014, 53, 10070- 10084.

35 T. J. Morin, S. Wanniarachchi, C. Gwengo, V. Makura, H. M. Tatlock, S. V. Lindeman, B. Bennett, G. J.

Long, F. Grandjean and J. R. Gardinier, Dalton Trans, 2011, 40, 8024-8034.

36 L. G. Lavrenova, Russ. Chem. Bull, 2018, 67, 1142- 1152.

37 D. L. Reger, J. R. Gardinier, J. D. Elgin, M. D. Smith, D. Hautot, G. J. Long and F. Grandjean, Inorg. Chem, 2006, 45, 8862-8875.

38 C. Hansch, A. Leo and R. W. Taft, Chem. Rev, 1991, 91, 165- 195.

39 A. M. Beaird, T. A. Davis and M. A. Matthews, Ind. Eng. Chem. Res, 2010, 49, 9596- 9599.

40 H. I. Schlesinger, H. C. Brown, A. E. Finholt, J. R. Gilbreath, H. R. Hoekstra and E. K. Hyde, J. Am.

Chem. Soc, 1953, 75, 215- 219.

41 O. V. Ozerov, C. Guo, L. Fan and B. M. Foxman, Organometallics, 2004, 23, 5573- 5580.

42 L.-C. Liang, P.-S. Chien and P.-Y. Lee, Organometallics, 2008, 27, 3082- 3093.

43D. Bao, B. Millare, W. Xia, B. G. Steyer, A. A. Gerasimenko, A. Ferreira, A. Contreras and V. I. Vullev, J. Phys. Chem. A, 2009, 113, 1259- 1267.

44 I. Noviandri, K. N. Brown, D. S. Fleming, P. T. Gulyas, P. A. Lay, A. F. Masters and L. Phillips, J. Phys.

Chem. B, 1999, 103, 6713-6722.

45 CrysAlisPro, Agilent Technologies, 2010.

46 G. M. Sheldrick, Acta Crystallogr., Sect. C, 2015, 71, 3- 8.

47 Y. Zhao and D. G. Truhlar, Theor. Chem. Acc, 2008, 120, 215- 241.

48 F. Weigend and R. Ahlrichs, Phys. Chem. Chem. Phys, 2005, 7, 3297- 3305. 
49 J. R. Gardinier, J. S. Hewage, B. Bennett, D. Wang and S. V. Lindeman, Organometallics, 2018, 37, 989- 1000.

50 G. Scalmani and M. J. Frisch, J. Chem. Phys, 2010, 132, 114110.

51 M. J. Frisch, G. W. Trucks, H. B. Schlegel, G. E. Scuseria, M. A. Robb, J. R. Cheeseman, G. Scalmani, V. Barone, B. Mennucci, G. A. Petersson, H. Nakatsuji, M. Caricato, X. Li, H. P. Hratchian, A. F. Izmaylov, J. Bloino, G. Zheng, J. L. Sonnenberg, M. Hada, M. Ehara, K. Toyota, R. Fukuda, J. Hasegawa, M. Ishida, T. Nakajima, Y. Honda, O. Kitao, H. Nakai, T. Vreven, J. A. Montgomery Jr., J. E. Peralta, F. Ogliaro, M. Bearpark, J. J. Heyd, E. Brothers, K. N. Kudin, V. N. Staroverov, R. Kobayashi, J. Normand, K. Raghavachari, A. Rendell, J. C. Burant, S. S. Iyengar, J. Tomasi, M. Cossi, N. Rega, J. M. Millam, M. Klene, J. E. Knox, J. B. Cross, V. Bakken, C. Adamo, J. Jaramillo, R. Gomperts, R. E. Stratmann, O. Yazyev, A. J. Austin, R. Cammi, C. Pomelli, J. W. Ochterski, R. L. Martin, K. Morokuma, V. G. Zakrzewski, G. A. Voth, P. Salvador, J. J. Dannenberg, S. Dapprich, A. D. Daniels, Ö. Farkas, J. B. Foresman, J. V. Ortiz, J. Cioslowski, D. J. Fox, Gaussian 09, Revision C.01, Gaussian, Inc., Wallingford CT, 2016.

52 G. Scalmani, M. J. Frisch, B. Mennucci, J. Tomasi, R. Cammi and V. Barone, J. Chem.

Phys, 2006, 124, 094107.

53 M. E. Casida, C. Jamorski, K. C. Casida and D. R. Salahub, J. Chem. Phys, 1998, 108, 4439- 4449.

54 A. D. Laurent and D. Jacquemin, Int. J. Quantum Chem, 2013, 113, 2019- 2039.

55 L. E. Roy, E. Jakubikova, M. G. Guthrie and E. R. Batista, J. Phys. Chem. A, 2009, 113, 6745- 6750.

56 S. J. Konezny, M. D. Doherty, O. R. Luca, R. H. Crabtree, G. L. Soloveichik and V. S. Batista, J. Phys. Chem. C, 2012, 116, 6349-6356.

57 L. Castro and M. Bühl, J. Chem. Theory Comput, 2014, 10, 243- 251. 